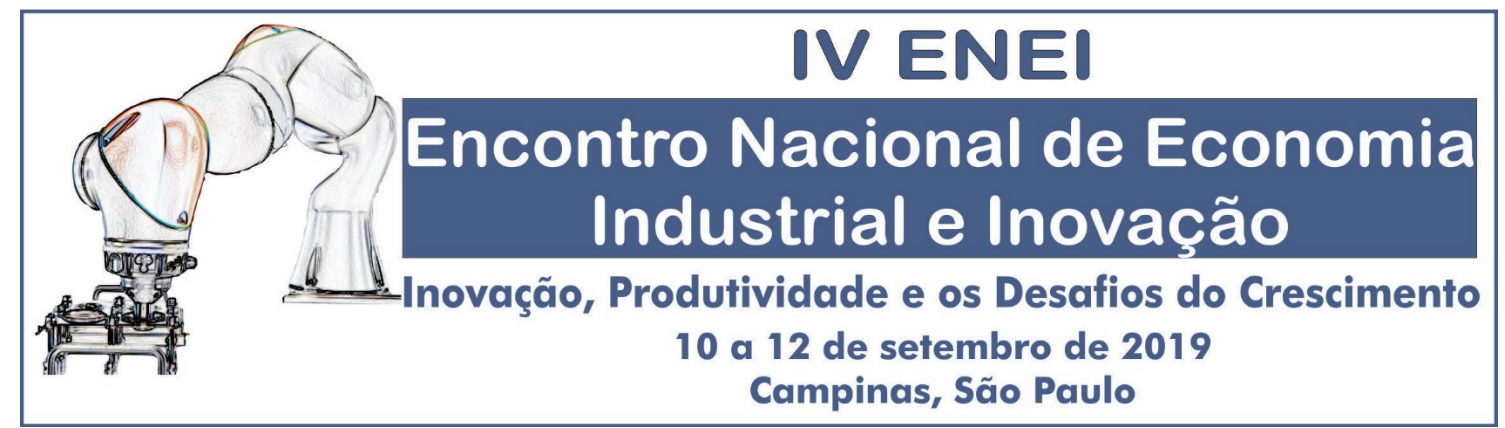

\title{
FINANCIAMENTO DA INOVAÇÃO TECNOLÓGICA E CONSOLIDAÇÃO FINANCEIRA DAS DÍVIDAS DE CURTO PRAZO EM PAÍSES EM DESENVOLVIMENTO
}

\author{
Carlos Roberto Gabriani* \\ Ricardo Dathein**
}

\begin{abstract}
Resumo: O processo inovativo requer que empresas inovadoras alavanquem recursos de curto prazo necessários para financiar suas inovações tecnológicas (finance). $\mathrm{O}$ descasamento de prazos entre obrigações financeiras e fluxos esperados das inovações impõe a necessidade de se alargar os prazos de suas dívidas (funding), para o qual o mercado de capitais desempenha papel de fundamental importância. O objetivo é discutir as relações entre setor bancário e mercados de capitais para o processo de consolidação financeira de dívidas, evidenciando como tais relações podem contribuir para o financiamento da inovação tecnológica em países em desenvolvimento, ou em processo de catching up. Visa-se estabelecer mecanismos que possam contribuir, do ponto de vista teórico, para uma melhor compreensão dos processos relacionados com o financiamento da inovação tecnológica. Pretende-se dar destaque ao papel do sistema bancário e dos mercados de capitais enquanto estruturas institucionais que se complementam no suporte ao financiamento do investimento e da inovação tecnologia. Para isso, a partir de uma base teórica póskeynesiana e schumpeteriana, analisam-se as relações entre sistema bancário e mercados de capitais, bem como sobre o financiamento bancário e a consolidação financeira das dívidas de curto prazo. Os principais resultados apontam para o fato de que as relações entre o sistema bancário e mercados de capitais são imprescindíveis para o processo de consolidação financeira de dívidas.
\end{abstract}

Palavras-chaves: Inovação tecnológica; Financiamento; Consolidação financeira.

\begin{abstract}
The innovative process requires innovative companies to leverage resources on short term necessaries to finance its techonogical innovations. The deviation in the terms between financial obligations and expected flows of innovations imposes that is necessary to lengthen the terms of its debts, for which capital market plays an important role. The aim is to discuss the relations between the banking sector and the capital market to the process of financial consolidation of debts, highlighting how such relations may contribute to the financing of technological innovation in developing countries or countries in processing of catching up. It is intended to establish mechanisms that can contribute, theoretically, to a better understanding of the processes related to the financing of technological innovation. The aim is to highlight the role of the banking system and the capital markets as institutional structures that complement each other in supporting investment financing and technology innovation. It is made an analysis regarding the relations between the banking system and the capital market, as well as an analysis regarding the bank financing and the financial consolidation of debts in the short term. The main results point to the fact that the relations between the banking system and capital markets are essential for the process of financial consolidation of debts.
\end{abstract}

\footnotetext{
Professor do Curso de Ciências Econômicas da Escola de Administração e Negócios, Fundação Universidade Federal de Mato Grosso do Sul. E-mail: carlos.gabriani@ufms.br.

${ }^{* *}$ Professor do Programa de Pós-Graduação em Economia, Faculdade de Ciências Econômicas, Universidade Federal do Rio Grande do Sul. E-mail: ricardo.dathein@ufrgs.br.
} 
Key-words: Technological innovation; Financing; Financial consolidation.

JEL: O39

\section{INTRODUÇÃO}

Pensar o financiamento da inovação tecnológica requer também pensar o processo de consolidação financeira das dívidas de curto prazo das empresas, dívidas estas alavancadas com recursos financeiros decorrentes de fontes de financiamento de curto prazo como, por exemplo, o crédito bancário. Conforme se depreende das abordagens pós-keynesianas, o finance fornecido pelos bancos tem sua contrapartida no funding: as empresas dependentes de fontes de recursos de curto prazo devem efetuar a consolidação financeira de suas dívidas através dos mercados de capitais. Nesse sentido, sistema bancário e mercados de capitais devem ser pensados em conjunto enquanto estruturas que se complementam e dão suporte ao financiamento do investimento e da inovação tecnológica. Desse modo, as empresas de países em desenvolvimento, ou em processo de catching up, os quais não apresentam mercados de capitais estruturalmente instituídos, têm dificuldades adicionais em termos do financiamento da inovação tecnológica.

Objetiva-se neste artigo estabelecer as relações existentes entre financiamento da inovação tecnológica e o processo de consolidação financeira das dívidas das empresas alavancadas com recursos financeiros de curto prazo via, por exemplo, o crédito bancário. Visa-se, no caso, estabelecer mecanismos que possam contribuir, do ponto de vista teórico, para uma melhor compreensão dos processos relacionados com o financiamento da inovação tecnológica, sobretudo para países em desenvolvimento, ou em processo de catching up. Nesse sentido, pretende-se dar destaque para o papel do sistema bancário e dos mercados de capitais enquanto estruturas institucionais que se complementam e dão suporte ao financiamento do investimento e da inovação tecnologia e ao processo de consolidação financeira das dívidas das empresas inversoras e inovadoras. Outro propósito é fazer uma revisão crítica sobre a taxonomia de Zysman sobre sistema financeiro e os efeitos das fases cíclicas da economia no processo de financiamento e de consolidação das dívidas de curto prazo.

Com o intento de atingir esses objetivos, o artigo encontra-se dividido em três seções, além desta introdução. Na primeira, faz-se uma discussão sobre as relações entre o sistema bancário, os mercados de capitais e o processo de consolidação financeira das dívidas de curto prazo das empresas, com destaque para o mecanismo finance-funding. Na segunda, faz-se uma abordagem sobre fatores que condicionam o financiamento do investimento e da inovação tecnológica postos pelo comportamento da firma bancária, pela demanda por crédito nas fases cíclicas e pelo comportamento dos agentes poupadores e investidos, que também influenciam as condições de oferta e demanda por empréstimos bancários para se financiar a acumulação de capital e a inovação tecnológica. Tais agentes condicionam o processo de consolidação financeira das dívidas de curto prazo e, por conseguinte, a capacidade das empresas inversoras/inovadoras de alavancarem recursos para financiar investimentos e/ou inovação tecnológica. Avança-se em relação a taxonomia de Zysman sobre sistema financeiro com o propósito de buscar elementos que corroborem com a ideia de que o sistema bancário e os mercados de capitais devem ser analisados em conjunto em termos das condições de financiamento do investimento ou da inovação tecnológica, tendo em vista o processo de consolidação financeira das dívidas de curto prazo, o que requer ações simultâneas e complementares dos dois setores: bancos para o fornecimento de finance e mercados de capitais para a consolidação financeira das dívidas (funding). Seguem as considerações finais.

\section{SISTEMA BANCÁRIO, MERCADOS DE CAPITAIS E CONSOLIDAÇÃO FINANCEIRA DAS DÍVIDAS DE CURTO PRAZO}

Studart (1999) destaca que uma alternativa pós-keynesiana à teoria convencional do processo de financiamento do investimento e da acumulação de capital precisa ser estruturada sobre dois pilares: em 
primeiro lugar, deve-se utilizar da crítica de Keynes à concepção neoclássica convencional e estruturar uma abordagem alternativa centrada no circuito finance-funding, em segundo lugar, é necessário observar que tal alternativa leva em consideração a existência de "modelo particular de sistema financeiro (no qual o sistema bancário é desenvolvido e existem mercados organizados de ativos financeiros". ${ }^{1}$ (STUDART, 1999, p. 156). Com a necessidade, destacada prontamente por Keynes, de que os investidores têm de efetuar a consolidação financeira de curto prazo - na terminologia de Keynes, "fundar as dívidas de curto prazo" - esta consolidação financeira torna-se procedimento de fundamental importância não somente para o processo de financiamento do investimento (acumulação de capital), ${ }^{2}$ mas fundamentalmente para o processo de financiamento da inovação tecnológica. Nesse aspecto Studart (1999) destaca que:

O empresário, quando decide investir, tem de se satisfazer em dois pontos: primeiro, deve poder obter um financiamento de curto prazo suficiente durante o período de produção do investimento; e, em segundo lugar, deve poder eventualmente consolidar, em condições satisfatórias, as obrigações de curto prazo através da emissão de títulos de longo prazo. Vez ou outra, o empresário pode utilizar-se de recursos próprios ou fazer emissão de [títulos e ações] de longo prazo diretamente, mas isso não modifica o volume de financiamento, que tem de ser encontrado pelo mercado como um todo, mas apenas o canal pelo qual [os recursos financeiros] chega[m] ao empresário e a probabilidade de que parte do volume possa ser levantado pela liberação de dinheiro do próprio bolso ou do resto do público. Dessa forma, é conveniente ver o processo duplo [financefunding] como característico [do financiamento do investimento] (STUDART, 1999, p. 160; grifos nossos). ${ }^{3}$

Com vistas a materializar elementos que possam contribuir para a estruturação de uma visão póskeynesiana alternativa, Studart (1999) passa a efetuar uma crítica ao ponto de vista do mainstrem sobre o financiamento do investimento. $\mathrm{O}$ autor destaca elementos como o papel do sistema bancário no processo de financiamento da acumulação de capital, a determinação e o papel da taxa de juros e suas influências sobre o investimento e o papel do mercado de capitais na alocação das poupanças individuais. Tais poupanças são geradas através do multiplicador de renda deflagrado pelos efeitos das despesas com a realização do investimento, como também pela realização de gastos com a implementação de inovações tecnológicas. As decisões de implementar inovações tecnológica, sobretudo nos países em desenvolvimento, ou em processo de catching up, sobretudo pelas empresas que não exercem liderança tecnológica nos setores em que atuam, devem ser consideradas como decisões de investir. Estas se consubstanciam na aquisição de bens de capitais que incorporam novas tecnologias, ou na obtenção de know-how, patentes e novos conhecimentos necessários para ampliar as competências e as capacitações tecnológicas (LUNDVALL, 1988; GRASSI, 2006) das empresas, como evidenciado pela Figura 01.

\footnotetext{
${ }^{1}$ Ao menos no estágio II de desenvolvimento do setor bancário, conforme Chick (2010), em que, superados os limites da concessão de crédito com base na disponibilidade prévia de depósitos, os bancos expandem os meios de pagamento através do mecanismo empréstimo-depósitos a partir do processo de emissão, com ampla aceitação como meios de pagamentos, de notas bancárias e direitos sobre depósitos. A partir deste estágio de desenvolvimento do setor bancário são as reservas e a preferência pela liquidez dos bancos, não mais os depósitos, que estabelecem os limites para a expansão do crédito e dos empréstimos bancários. Isso torna possível, desde então, aos bancos efetuarem a administração de suas estruturas contábeis passivas e ativas, amparados pela postura de complacência dos bancos centrais de homologarem a expansão dos meios de pagamentos, realizada pelos bancos comerciais, através de ações como emprestadores de última instância, conforme destacado por Minsky (2008).

${ }^{2}$ Segundo Boianovsky (1992), "O processo típico de financiamento é apresentado no quinto parágrafo do [artigo] 'A teoria ex ante ...', onde Keynes distingue duas etapas: o financiamento de curto prazo (para financiar a produção do bem de capital) e de 'longo prazo' ([esta] não é a expressão utilizada por Keynes, mas traduz o processo de 'fundar' a dívida de curto prazo, isto é, transformá-la numa relação de longo prazo através da emissão de ações). $O$ crédito demandado pela firma no curto prazo é constituído pela demanda de moeda exercida pela firma no intervalo de tempo entre a decisão de investimento e sua implementação, que se encerra no momento da efetivação do investimento. Essa demanda [...] é denominada por Keynes 'motivo financiamento' (finance motive), que o distingue sobremaneira do sentido dado por Ohlin ao termo 'crédito líquido'. Trata-se de um estoque de moeda demandada, que necessariamente leva algum agente do sistema econômico a diminuir sua [preferência por] liquidez, pressionando, assim, a taxa de juros. Esse agente é tipicamente o banco comercial" (BOIANOVSKY, 1992, p. 301; grifo nosso).

${ }^{3}$ Deve-se aqui chamar a atenção para uma questão de interpretação. Usou-se a tradução de Studart no livro Macroeconomia Moderna, que é diferente da tradução do livro Clássicos de Literatura Econômica. Studart interpreta Keynes (tradução livre do autor) conforme: "o empresário, quando decide investir, tem de se satisfazer em dois pontos: primeiro, deve poder obter um financiamento de curto prazo suficiente durante o período de produção do investimento" (LIMA et al., 1999, p. 160; grifo nosso). Na tradução de Clássicos de Literatura Econômica: "quando o empresário decide investir, precisa estar seguro de dois pontos: primeiro, que pode obter recursos suficientes a curto prazo, durante o período de produção do investimento" (IPEA, 1992, p. 336; grifo nosso). Ora, "obter financiamento de curto prazo" (crédito bancário, inclusive) é diferente de "obter recursos [...] a curto prazo". Aquele significa obter capital cujo contrato de obtenção tem vencimento no curto prazo; este significa obter capital a curto prazo, ou seja, de imediato, rapidamente, mas que não necessariamente seja de curto prazo. A obtenção de capital a curto prazo pode inclusive se dar através de rápido processo de subscrição de novas ações e títulos nos mercados de capitais, e isso não necessariamente significa financiamento de curto prazo. A nosso ver, a curto prazo é possível o investidor captar recursos de curto prazo (crédito bancário de curto prazo), como também de longo prazo (empréstimos de longo prazo, lançamentos de títulos e ações). Segundo Keynes (1937b): “The entrepreneur when he decides to invest has to be satisfied on two points: firstly, that he can obtain sufficient short-term finance during the period of producing the investment" (KEYNES, 1937b, p 664; publicação original).
} 
Deve-se destacar aqui a importância dos mercados de capitais para o processo de financiamento da acumulação de capital e do investimento, no geral, e da inovação tecnológica, em particular. Tal financiamento se dá através de vários mecanismos, entre os quais a subscrição de novos títulos de longo prazo e ações não apenas para alavancagem direta de planos de investimentos ou com inovações tecnológicas, mas também para a consolidação financeira das dívidas de curto prazo das empresas endividadas nos mercados de crédito bancário. Geralmente a abordagem pós-keynesiana dá ênfase mais para o primeiro fator, negligenciando o papel da consolidação financeira das dívidas de curto prazo.

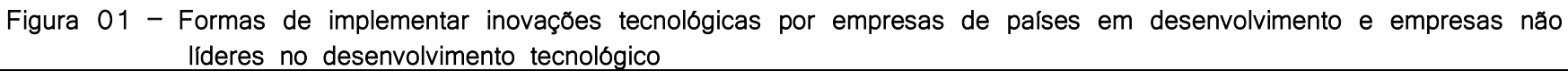
líderes no desenvolvimento tecnológico

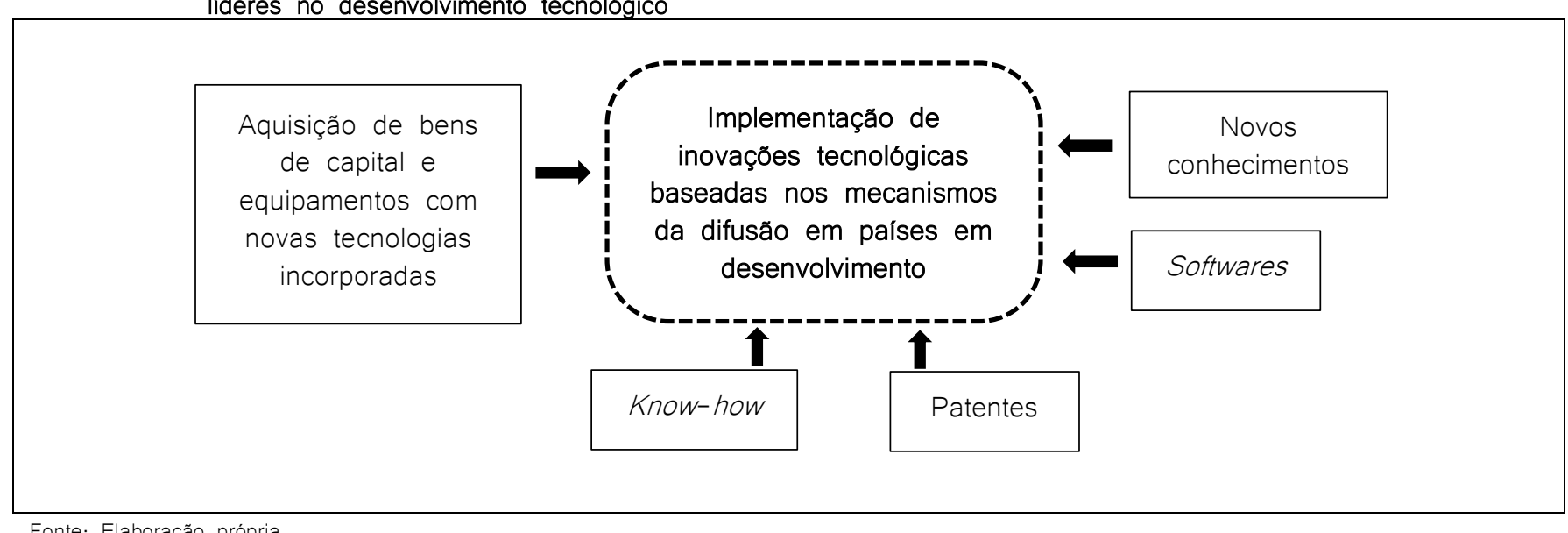

Fonte: Elaboração própria.

A importância desta última questão é corroborada por Studart (1999), amparado nas interpretações de Keynes, que desenvolve uma abordagem alternativa à visão do mainstream sobre o financiamento do investimento e o papel das instituições financeiras em uma economia de decisões empresariais. Segundo Keynes, quando o empresário decide investir deve, por um lado, poder angariar financiamento de curto prazo, sobretudo através de obtenção de crédito bancário ${ }^{4}$. Deve também, por outro lado, poder efetuar a consolidação financeira de tais dívidas através da emissão de títulos de longo prazo, equalizando, desse modo, os prazos de retorno dos investimentos realizados, ou os resultados prospectivos das inovações implementadas, com os prazos de vencimentos de suas dívidas contraídas junto aos bancos. Nesse aspecto, Studart (1999) destaca ainda que,

$\mathrm{Na}$ ausência [de possibilidade] de consolidação financeira, ou os bancos seriam obrigados a reduzir a margem de segurança, ou os investidores seriam obrigados a rolar o passivo de longo prazo [ou melhor, os seus passivos de curto prazo; seus empréstimos contraídos junto ao sistema bancário] até [que ocorra] a maturação e o retorno dos investimentos (STUDART, 1999, p. 160). ${ }^{5}$

Essas possibilidades têm implicações do ponto de vista do aumento do grau de fragilidade financeira da economia, segundo a visão de Minsky (2008). Contudo, como tais alternativas estão descartadas para o estágio de desenvolvimento dos sistemas financeiros desde a abordagem de Keynes, ${ }^{6}$ e sobretudo para

\footnotetext{
${ }^{4}$ Até este ponto, percebe-se uma sintonia entre a abordagem de Keynes e de Schumpeter. Para ambos o financiamento do investimento e da inovação requer a presença de sistema financeiro capaz de gerar e gerir os fundos necessários ao financiamento da acumulação de capital. Entretanto, se Schumpeter desconsidera, ou melhor, não analisa a questão referente à forma de como o sistema bancário promove a oferta de crédito - posição diferente é assumida no Capitalismo, Socialismo e Democracia (SCHUMPETER,1984), quando pressupõe que o financiamento à inovação advém dos lucros das grandes empresas -, Keynes, por sua vez, não analisa a questão do processo de inovação e suas necessidades de recursos financeiros. Contudo, deve-se avançar, e esta é a proposta deste trabalho, no sentido de se estruturar uma análise financeira do sistema capitalista de produção moderno centrada nas abordagens de ambos os autores. É na confluência das abordagens financeiras de Keynes e Schumpeter que poderemos encontrar elementos teóricos que permitem uma compreensão melhor do funcionamento do sistema capitalista de produção moderno.

${ }^{5}$ Os investidores deveriam rolar seus passivos de curto prazos, ou seja, seus empréstimos junto aos bancos comerciais, contraídos para financiar investimentos ou inovações, pelo tempo necessário até que os retornos, tanto dos investimentos quanto das inovações tecnológicas, possam prover recursos financeiros para saldá-los junto aos bancos.

${ }^{6}$ Segundo Paula (1998) "Levando-se em conta Hicks (1967, cap. 9), para quem a teoria monetária está condicionada fortemente pelo momento histórico e a experiência particular de cada autor, parte-se do pressuposto de que as ideias de Keynes sobre o sistema bancário, desenvolvidas particularmente no seu Treatise on money, de 1930, assim como as de Minsky, especialmente no Stabilizing an Unstable Economy, de 1986, são frutos, em boa medida, do contexto histórico em que cada um estava imerso. Mais especificamente, as de Keynes correspondem ao estágio IV da evolução do sistema bancário estilizada por Chick (1993), em The evolution of the banking system and the theory of saving, investment and interest; ou seja, o estágio em que o banco central já existe
} 
sistema de produção capitalista moderno, resta como alternativa a necessidade de se buscar elementos que possam contribuir para a compreensão e o entendimento do processo de financiamento através do uso do crédito bancário. Outra saída é associar os mecanismos de financiamento bancário à possibilidade de consolidação financeira das dívidas de curto prazo das empresas através da venda de títulos de dívidas ou de propriedade nos mercados de capitais. É apenas com a compreensão e a incorporação do processo de consolidação financeira das dívidas de curto prazo no arcabouço teórico sobre o financiamento do investimento e da inovação que se pode construir uma teoria mais completa e realista do financiamento. ${ }^{7}$

Sem considerar as possibilidades e as condições efetivas de consolidação financeira das dívidas de curto prazo, o crédito bancário apresenta dificuldades de se constituir em fonte alternativa eficaz de financiamento da acumulação capital e da inovação tecnológica. Portanto, não é possível conceber o crédito bancário como alternativa de financiamento do investimento e de gastos com a implementação de inovação tecnológica desassociado do processo de consolidação financeira das dívidas de curto prazo. Se assim não for, o empresário investidor ou inovador se verá peremptoriamente diante de dificuldades relacionadas ao descasamento dos prazos de retornos dos investimentos, ou da obtenção de resultados positivos das inovações tecnológicas implementadas, em relação aos prazos de ressarcimentos do principal e dos juros das dívidas contraídas junto ao sistema bancário através dos empréstimos, conforme a Figura 02.

Figura 02 - Sobreposiçăo dos objetivos e resultados de curto e longo prazos dos investimentos e das inovaçőes tecnológicas

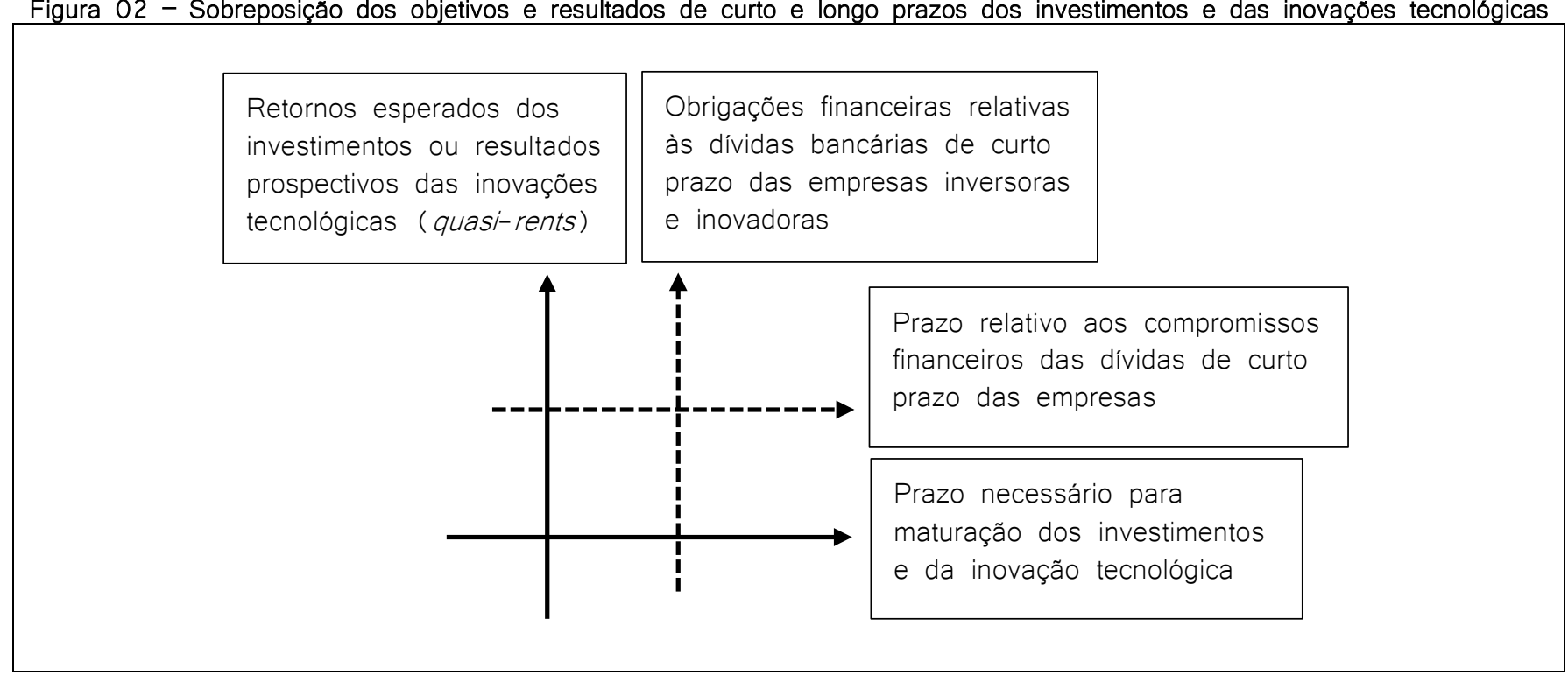

Fonte: Elaboração própria.

É necessário destacar, entretanto, que os objetivos e os resultados de curto prazo estão circunscritos e perpassam pelos objetivos e resultados de longo prazo; ou seja, os prazos relativos aos compromissos financeiros de curto prazos requerem não apenas um fluxo de caixa de curto prazo capaz de proporcionar o volume de recursos financeiros suficientes para as empresas inversoras/inovadoras honrarem seus compromissos financeiros, mas também a consolidação financeira das dívidas de curto prazo das empresas de maneira a permitir que as mesmas tenham condições de sincronizar fluxos prospectivos de renda com fluxos de compromissos financeiros bancários no longo prazo.

como emprestador de última instância e os bancos, ao terem acesso a reservas adicionais junto ao banco central, podem atuar de forma mais agressiva, respondendo dinamicamente a aumento da demanda por crédito dos agentes e expandindo, assim, suas operações de crédito além da capacidade determinada pelas reservas do sistema. A visão de Minsky sobre o sistema bancário, por sua vez, corresponde ao estágio V, mais avançado, em que os bancos passam a atuar dinamicamente nos dois lados do seu balanço, desenvolvendo técnicas de administração do passivo (liability management), o que faz com que os depósitos deixem de se constituir em parâmetro exógeno (e consequência passiva da política de empréstimos) aos bancos, como resultado do acirramento da concorrência entre as instituições bancárias na busca ativa por oportunidades lucrativas" (PAULA, 1998, p. 22).

${ }^{7}$ Dessa perspectiva, uma teoria do financiamento do investimento e da inovação que leve em consideração os mecanismos e as implicações decorrentes do processo de consolidação das dívidas de curto prazo das empresas inversoras/inovadoras, deve constituir-se em uma teoria mais estruturante, fundada em aspectos mais concretos e realistas. 
Desse modo, podemos concluir que o finance, via crédito bancário, só pode constituir-se como uma alternativa de financiamento do investimento ${ }^{8}$ e da inovação tecnológica, se estiver diretamente associado ao funding. Isso requer a presença simultânea não só do sistema bancário, com o seu papel de expansão dos meios de pagamento via criação de moeda através do mecanismo de crédito-depósito, como também, e fundamentalmente, dos mercados de capitais, com o seu papel no processo de consolidação financeira das dívidas de curto prazo das empresas inversoras ou inovadoras. Ou seja, o crédito bancário só se torna funcional para o financiamento da inovação tecnológica, segundo Schumpeter (1982), ou para o financiamento da acumulação de capital e do investimento, segundo Keynes (1985) e Kalecki (1985), se associado simultaneamente ao processo de consolidação financeira das dívidas de curto prazo. Isso, entretanto, requer a existência de sistema de mercados de capitais estruturado, consolidado e funcional, com ações que possam complementar as ações desempenhadas pelo sistema bancário no processo de financiamento da acumulação de capital e da inovação tecnológica.

Em paralelo, numa economia monetária de produção, em que a dinâmica concorrencial se dá através da inovação tecnológica, segundo as abordagens schumpeteriana e neo-schumpeteriana, tem-se a tomada de decisões de implementar gastos com inovações.

Para as empresas que não exercem a liderança tecnológica em seus setores, implementando inovações através do acesso a mecanismos da difusão tecnológica, tais decisões se dão através da obtenção de novos bens de capital - que incorporam novas tecnologias produtivas -, ou por intermédio de aquisição de patentes, know-how e novos conhecimentos gerados externamente às atividades inovativas das empresas. Essas decisões de gastos com inovações tecnológicas, realizados com vista à obtenção ou ao aumento dos rendimentos futuros, devem ser consideradas no processo de tomada de decisões do agente empresarial que atua numa economia empresarial ou monetária, mas que também é uma economia cujo a dinâmica é ditada pelo processo de inovação tecnológica, segundo a abordagem schumpeteriana. Isso significa que os empresários devem considerar, em seu processo decisório de investir, não apenas os fatores pertinentes quanto ao preço dos bens de capital, aos riscos envolvidos, aos retornos esperados dos mesmos e às possibilidades de encontrar e obter finance para iniciar seus planos de investimentos e de gastos com inovações a serem implementadas, mas também devem levar em conta e analisar de forma adequada os elementos pertinentes às possibilidades e condições efetivas de "fundarem" suas dívidas de curto prazo.

Contudo, a abordagem teórica pós-keynesiana não tem dado a devida atenção a este elemento em razão de, em certo sentido, o estar subjacente à questão dos retornos dos investimentos na abordagem de Keynes na Teoria Geral na medida em que, segundo esta visão, se os retornos esperados forem superiores aos compromissos de desembolsos financeiros com obrigações contratadas, o investimento é, por si só, uma certa garantia de seu financiamento, não necessitando assim de consolidação das dívidas. Entretanto, apresentar nível de rentabilidade superior aos compromissos com desembolso financeiro contratados constitui não apenas condição necessária para que o investidor possa obter financiamento externo, inclusive através do mercado de crédito bancário, mas também possibilita estabelecer garantias ao agente financeiro de que o investidor poderá honrar compromissos financeiros com dívidas contraídas.

O que se pretende demonstrar é que os retornos esperados, relativos aos planos de investimentos e de inovação, não devem ser vistos apenas como parâmetro determinante das decisões de investir tomadas pelo empresário keynesiano, mas também parâmetros para banqueiros decidirem ou não a concessão de crédito. Se empresário keynesiano e o banqueiro fossem agentes econômicos personificados em único indivíduo tomador de decisões, não haveria a necessidade da dupla expectativa: de um lado, as dos empresários quanto aos retornos esperados de seus capitais e, de outro, as dos banqueiros quanto à capacidade daqueles de honrar seus compromissos financeiros contratados.

O próprio Keynes destacou que uma vez que os fluxos de caixas dos valores esperados, ou os quasirents, decorrentes dos investimentos - o que também vale para os resultados prospectivos das inovações tecnológicas implementadas - sejam superiores aos fluxos de pagamentos referentes às dívidas contraídas, as decisões de investir, assim também as decisões de implementar inovações, seriam tomadas e implementadas. A interpretação de que se os fluxos prospectivos de caixa forem superiores aos fluxos de

\footnotetext{
${ }^{8}$ Conforme Keynes (1937a, 1937b) pós publicação da Teoria Geral do Emprego, do Juro e da Moeda. Para uma análise mais detalhada sobre o debate que se travou entre Keynes e seus interpretes acerca dos determinantes do investimento, da taxa de juros e do financiamento, ver os artigos publicados no livro Clássicos de Literatura Econômica, do IPEA (1992).
} 
desembolso relativos aos compromissos financeiros com as dívidas torna a questão do financiamento do investimento um tanto velada, razão pela qual a abordagem pós-keynesiana pouco tem contribuído para seu desenvolvimento teórico.

De outro modo, está subjacente nas interpretações da abordagem pós-keynesiana que os fluxos de caixas dos valores esperados dos investimentos e dos resultados prospectivos das inovações implementadas tornam possíveis os pagamentos das dívidas. Isso pode levar a abordagem pós-keynesiana a também negligenciar, ou a também não dar a devida importância para questões relativas ao papel dos mercados de capitais no financiamento do investimento e da inovação tecnológica, negligenciando assim o processo de consolidação financeira das dívidas de curto prazo das empresas. Esse processo envolve não apenas os mercados financeiros e de capitais, como também novos agentes econômicos como, por exemplo, os poupadores individuais e, mais recentemente, os fundos mútuos de pensões e de investimentos. Entretanto, tal possibilidade (ou seja, não ter que deparar-se com dificuldades em relação ao ressarcimento das dívidas contraídas) constitui-se em questão completamente diferente da relacionada às possibilidades e condições efetivas que determinam e condicionam o processo de consolidação financeira das dívidas de curto prazo das empresas através de mecanismos instituídos e disponíveis nos mercados de capitais. A razão disso é que os fluxos de retornos esperados dos investimentos e os resultados prospectivos dos investimentos e das inovações tecnológicas não são, e nada indica que possam ser, numa economia capitalista em que prevalecem elementos de incertezas, coincidentes com os desembolsos relativos aos pagamentos de dívidas contraídas junto ao sistema bancário, dados o caráter e a predominância de ações de curto prazo dos bancos. Tal diferença - ou seja, o descasamento temporal dos fluxos dos retornos e resultados prospectivos dos investimentos e da inovação tecnológica com as obrigações de desembolsos financeiros - decorre do processo de consolidação financeira das dívidas, que envolve também outros atores econômicos. Estes últimos são as instituições relativas ao mercado de capitais como, por exemplo, bolsas de valores, seguradoras, corretoras de títulos e valores mobiliários, bem como os fundos mútuos de pensões e investimentos, agentes estes que possuem expectativas próprias. De outra parte, aquele processo também envolve investidores institucionais, tais como fundos mútuos de investimentos e de pensões, e agentes poupadores individuais, com rendas excedentes aos seus gastos, que irão transferir poder de compra excedente para o futuro, ou manter parte de sua renda não gasta na forma de aplicações financeiras em títulos de dívidas ou de propriedades, comercializados nos mercados de capitais. Tais instituições e agentes também agem sob efeitos de expectativas e motivações individuais específicas que influenciam suas ações quanto ao volume ou parte da renda que será poupada e quanto à forma, ou instrumentos financeiros em que deverão manter tal poder de compra diferido. Tais expectativas e motivações individuais destes agentes influenciam as condições referentes ao processo de consolidação das dívidas de curto prazo dos empresários investidores e inovadores na medida em que proporciona maior ou menor liquidez aos novos títulos de dívidas de longo prazo e às novas ações, lançados nos mercados de capitais para fundar as dívidas de curto prazo.

Deve-se destacar que a forma como os agentes poupadores e investidores institucionais transferem para o futuro poder de compra está relacionada com a estrutura, a consolidação, a eficácia e a volatilidade dos preços de títulos e ações dos mercados de capitais. É notório que estes fatores influenciam as expectativas e a confiança dos agentes poupadores individuais e dos investidores institucionais em relação às suas decisões em termos do volume da renda não gastar e em termos da composição de seu portfólio. Quanto maior for o grau de confiança desses agentes nas expectativas em relação à estabilidade dos preços dos títulos de dívidas e de propriedades de longos prazos negociados nos mercados financeiros e de capitais, ou, de outra forma, quanto menor for a volatilidade e, portanto, maior for a estabilidade nos mercados financeiros e de capitais, maior tende a ser a preferência dos agentes poupadores individuais e dos investidores institucionais por manter tais títulos em seu portfólio de aplicações como forma de transferir e conservar poder de compra, resultante de excedente de renda, para o futuro. Se os preços dos títulos de dívidas e de propriedades negociados nos mercados financeiros e de capitais sofrem variações com frequência elevada e de amplitudes significativas, os agentes poupadores individuais e investidores institucionais tendem a estabelecer preferências não apenas em relação a outras formas alternativas de aplicações, mas também direcionar suas aplicações para outras praças financeiras. Esses agentes e investidores institucionais variam suas aplicações em termos dos títulos que compõem seus portfólios de 
aplicações, alterando assim os instrumentos pelos quais transferem poder de compra, resultante de excedentes de rendas, para o futuro. Isso tem implicações em termos das condições de financiamento da acumulação de capital e da inovação tecnológica em razão de que tais fatores influenciam as possibilidades e condições efetivas para a realização do funding, conforme pode ser visto através da Figura 03.

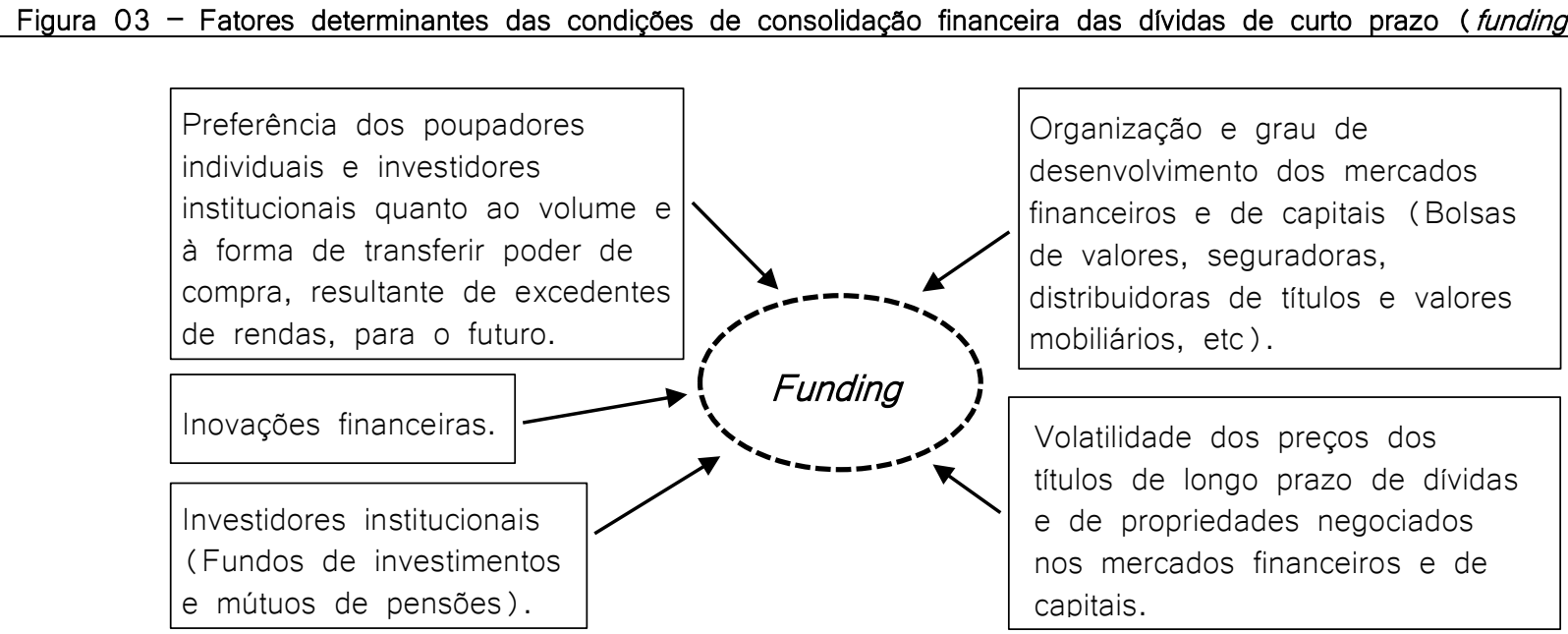

Fonte: Elaboração própria.

Studart (1999) já aponta nesta direção ao afirmar que “[...] num mundo incerto [...] o funding estaria condicionado pela propensão do público a adquirir títulos de longo prazo ou ações ao longo do processo de multiplicação da renda" (STUDART, 1999, p. 161; grifos nossos). ${ }^{9}$ Entretanto, deve-se destacar que os títulos financeiros de longo prazo ou ações (títulos de propriedades) são meramente duas alternativas, entre outras disponíveis ao público, para a manutenção de excedente de poder de compra transferido para o futuro. Tais opções, assim como qualquer outra, estão relacionadas ao estado de expectativas dos agentes poupadores individuais e investidores institucionais, sobretudo em razão da volatilidade de preços desses ativos nos mercados de capitais - como bem já destacou Keynes em sua teoria da preferência pela liquidez - e com a performance da economia. Portanto, as expectativas dos agentes poupadores individuais e investidores institucionais quanto às variações de preços dos ativos financeiros eleitos e mantidos em seus portfólios ${ }^{10}$ afetam as possibilidades e condições efetivas de consolidação financeira das dívidas de curto prazo através do funding. Isso tem reflexos diretos sobre o comportamento dos empresários inversores e inovadores quanto às decisões de realizar investimentos e efetuar gastos com a implementação de inovações tecnológicas; sobretudo, quando tais decisões devem ser financiadas através de crédito bancário de curto prazo, tendo em vista afetarem as condições de consolidação financeira das dívidas.

Esta questão não tem merecido a devida atenção pela abordagem pós-keynesiana, dada sua importância para o processo de financiamento. O que se pretende destacar, portanto, é que o financiamento do investimento e da inovação tecnológica (finance) não pode ser pensado de forma desassociada do processo de consolidação financeira das dívidas de curto prazo (funding). Financiamento, via crédito bancário, e funding são elementos intrinsecamente relacionados em razão da existência de dificuldades reais e concretas interpostas pelo descasamento entre, de um lado, a incerteza quanto aos retornos dos

\footnotetext{
${ }^{9}$ É consenso na literatura que o funding - ou a consolidação financeira das dívidas - baseia-se na troca de títulos de dívidas de curto prazo, compostos basicamente por empréstimos bancários, por títulos de dívidas de longo prazo. Entretanto, um fator negligenciado pela abordagem pós-keynesiana sobre o processo de financiamento do investimento e da inovação tecnológica implementada pelas empresas, que será analisado a seguir, é que essa permuta entre títulos de dívidas de curto prazo por títulos de longo prazo só pode ser realizada através do lançamento de novos títulos de dívidas ou de propriedades pelas empresas inversoras ou inovadoras. Isso implica no fato de que nem todas as empresas que se utilizam do crédito bancário para dar o start nos projetos de investimento e na implementação de inovações são de capital aberta, sendo, portanto, listadas em bolsas de valores. Isso implica que aquelas que não tem seu capital aberto não teria condições de realizar a consolidação financeira de suas dívidas de curto prazo por estarem impedidas de negociar títulos em bolsas. Desse modo, a consolidação financeira das dívidas de curto prazo só está disponível para as empresas listadas. Além disso, dadas as mudanças econômicas conjunturais que afetam o mercado de capitais, nem sempre o momento em que as empresas têm a necessidade de trocar dívidas de curto prazo por de longo prazo deve coincidir com o momento adequado de lançamento e subscrição de novos títulos a serem negociados em bolsas de valores, fator este que impõe dificuldades adicionais ao processo de consolidação financeira das dívidas de curto prazo.

${ }^{10}$ Assim como também quanto à taxa de juros e ganhos ou perda de capital - fatores estes relacionados com o comportamento dos agentes bulls e bears, conforme destacado por Keynes no A Treatise on Money.
} 
investimentos e das inovações tecnológicas implementadas e, de outro, os fluxos dos compromissos financeiros impostos pela alavancagem via crédito bancário. Além de tal descasamento, há ainda as consequências decorrentes das expectativas dos agentes poupadores individuais e dos investidores institucionais em manterem e transferirem para o futuro o poder de compra e os excedentes de rendas. A forma como esse poder de compra é composta em termos dos ativos financeiros preferidos, mantidos e conservados por tais agentes em seus portfólios afeta as possibilidades e as condições efetivas do processo de consolidação das dívidas de curto prazo. ${ }^{11}$ Dessa maneira, fica evidente que as expectativas quanto às possibilidades e condições efetivas de consolidação financeira das dívidas de curto prazo tornam-se fatores fundamentais do processo de financiamento do investimento e da inovação tecnológica, condicionando assim não apenas o volume de investimento e a acumulação de capital, mas também os gastos com implementação de inovações tecnológicas efetuados pelas empresas não líderes nos setores em que atuam e pelos países em desenvolvimento, em processo de catching up.

É lícito também pensar que em países que apresentam deficiências significativas em termos de estrutura, consolidação, organização e funcionamento de seus mercados de capitais, o crédito bancário pode ter sua eficácia e eficiência reduzidas em termos de constituir-se efetivamente em fonte alternativa de recursos financeiros para as empresas financiar o investimento e a implementação de inovações tecnológicas. Isso se dá em decorrência de o funding, ou o processo de consolidação financeira das dívidas de curto prazo, que constitui a fase complementar deste mecanismo de financiamento, configurar-se como elemento praticamente inoperante em razão das deficiências estruturais e organizacionais no funcionamento dos mercados de capitais nos países em desenvolvimento, em processo de catching up. Ou seja, se determinado país apresenta deficiências na estrutura e organização de seus mercados de capitais - o que parece ser a característica predominante da maioria dos países em desenvolvimento, conforme Zysman (1983) e Studart (1999) - o processo de consolidação financeira das dívidas de curto prazo nos mercados de capitais dos mesmos torna-se truncado, obstruindo a tomada de decisões quanto a implementar gastos com investimentos e com inovações tecnológicas. Isso restringe, assim, o uso do crédito bancário como fonte de recursos para o financiamento da acumulação de capital e das inovações tecnológicas em tais países. Portanto, as nações em desenvolvimento, em processo de catching up, apresentam em sua maioria deficiência em termos de composição da fonte de financiamento composta pelo crédito bancário. Isso ocorre não apenas por causa dos limites estabelecidos pelo funcionamento do mercado de crédito bancário, mas também em razão de circunstâncias que impõem limites para o processo de consolidação financeira das dívidas de curto prazo das empresas inversoras e inovadoras. Esses limites são instituídos pela precariedade relativa à estrutura, à consolidação e ao funcionamento dos mercados de capitais de tais países.

Desse modo, pode-se afirmar que as decisões empresariais de investir em estoque de capital físico (acumulação de capital) ou de implementar inovações tecnológicas, financiadas via crédito bancário, estão sob os efeitos de dois fatores: de um lado, são limitada pelas preferências pela liquidez dos bancos, que condicionam o finance através da criação de moeda, da expansão dos meios de pagamento pelo mecanismo de concessão de créditos-depósitos e a oferta de crédito na economia; de outro lado, são molduradas pelas decisões empresariais relativas a gastos com investimentos e inovações, sendo que estas, por sua vez, estão condicionadas pelas preferências dos agentes poupadores individuais e investidores institucionais em manter e transferir para o futuro poder de compra resultantes de excedentes de rendas. De outra parte, as referidas decisões também dependem da forma como os agentes compõem seus portfólios de aplicações. Tais fatores condicionam o funding e, por conseguinte, as possibilidades e condições efetivas de consolidação financeira das dívidas de curto prazo das empresas inversoras e inovadoras, impactando o volume de recursos destinado ao financiamento da acumulação de capital e dos gastos com inovações tecnológicas. Tais decisões estão circunscritas, de um lado, pelas incertezas relativas aos níveis de riscos de crédito e de default que os bancos estariam dispostos a suportar e, de outro, pelas incertezas quanto ao volume de recursos que os agentes poupadores individuais e investidores institucionais estariam dispostos a manter e a transferir para o futuro sob a forma de poder de compra diferido, conforme pode ser visto

\footnotetext{
${ }^{11}$ Disso Studart (1999) conclui que, em razão de diferenças nos horizontes de tempo das aplicações dos investidores produtivos e dos poupadores individuais, os bancos, assim com a maioria das instituições financeiras, desempenham papel fundamental na acomodação de tais horizontes. Essas instituições conciliam prazos e permitem "A diversificação de ativos colocados à disposição das unidades superavitárias [...] e a administração de estruturas passivas e ativas com diferentes horizontes de maturação" (STUDART, 1999, p. 161).
} 
através da Figura 04. Cabe destacar ainda que os níveis de riscos suportados pelos bancos estão diretamente associados à fase cíclica do crescimento econômico, conforme Minsky (2008) ao enfatizar, segundo a hipótese da fragilidade financeira, que nos períodos de boom tanto os bancos quanto os empresários inversores e inovadores colocam-se menos avessos a riscos, fator que resultaria no aumento da fragilidade financeira da economia e na subsequente reversão cíclica. ${ }^{12}$

Figura 04 - Fatores influentes nas decisóes empresariais de investir e inovar

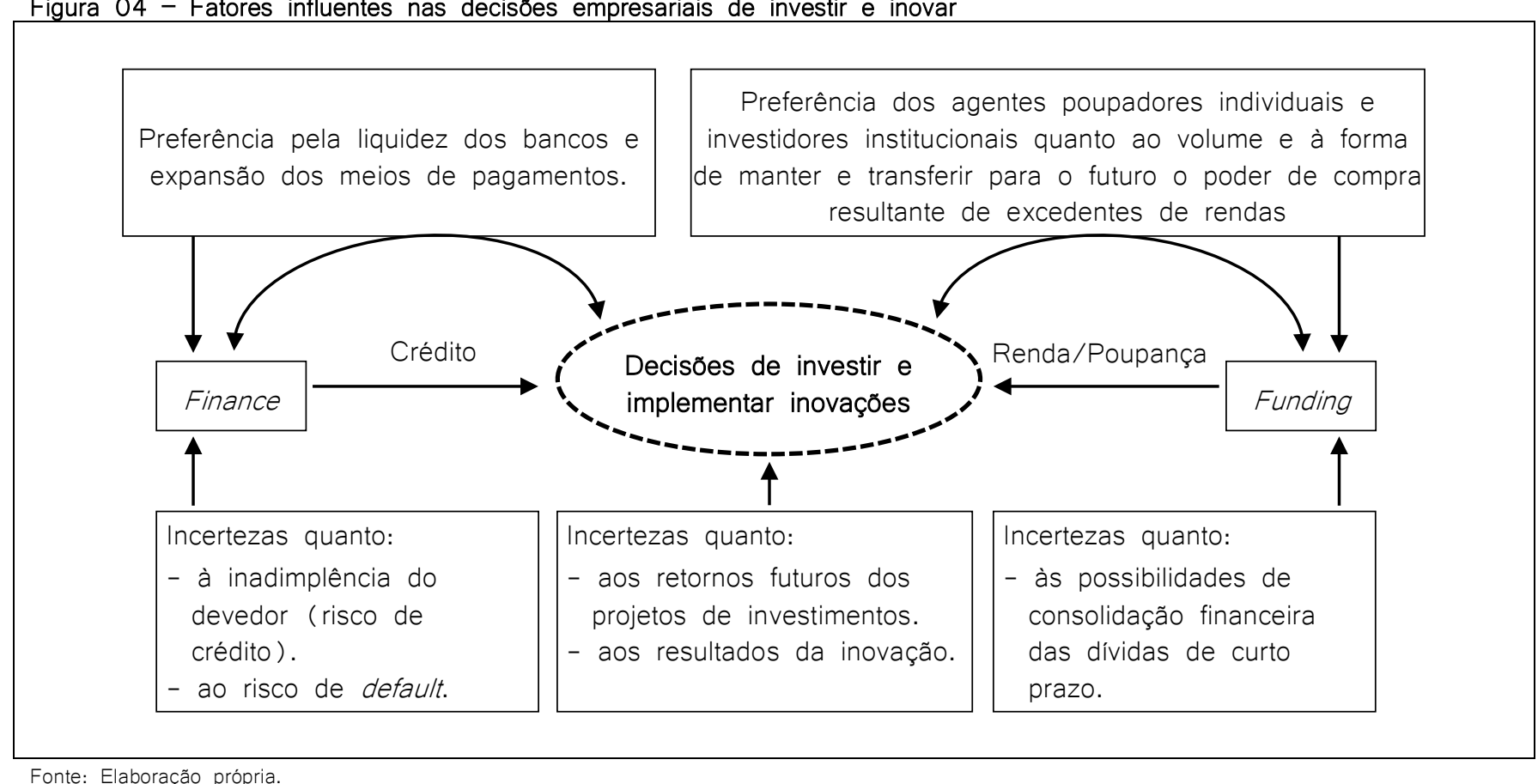

Fonte: Elaboração própria.

Constata-se, portanto, que a demanda por finance, a que os bancos devem atender, está diretamente relacionada, e é proporcional, à demanda por instrumentos financeiros de longo prazo realizadas pelos agentes poupadores individuais e investidores institucionais, como forma de os mesmos transferir para o futuro e manter poder de compra decorrente de excedentes de rendas. Assim, na contrapartida do volume de crédito destinado ao financiamento dos investimentos e da inovação tecnológica, realizados pelo sistema financeiro de cada país, deve existir um determinado volume de títulos de dívidas de longo prazo e de títulos de propriedades, lançados pelas empresas nos mercados de capitais, para fazer frente ao processo de consolidação financeira de suas dívidas bancárias. Desse modo, o volume de crédito destinado pelo sistema financeiro, seja para financiar a acumulação de capital ou para os gastos com inovações tecnológicas, está intimamente e diretamente relacionado com o volume de títulos e ações lançados pelas empresas endividadas, com vistas ao processo de consolidação financeira de suas dívidas, e negociados nos mercados de capitais.

Do exposto, podemos concluir que a funcionalidade dos bancos em realizar empréstimos para financiar investimento e inovação tecnológica das empresas evidencia, com base nas interpretações de Keynes e das abordagens pós-keynesianas, não somente que a poupança é gerada com a expansão da renda resultante dos gastos com investimentos e com implementação de inovações, ${ }^{13}$ mas também que parte dela deva ser carreada pelos agentes poupadores para a aquisição de títulos de longo prazos de dívidas ou de propriedades como forma de viabilizar o funding e a consolidação financeira das dívidas de curto prazo das empresas endividadas financiadas através do crédito bancário. Sobre tais fatores, nem bancos, tampouco

\footnotetext{
${ }^{12}$ Segundo Minsky (2008), existem relações entre as fases cíclicas da economia e o comportamento dos bancos quanto à criação de meios de pagamentos e expansão do crédito nas economias financeiramente modernas. Tal comportamento está respaldado em suas estratégias de preferir liquidez, em momentos de retração das atividades produtivas ou de recessão econômica, ou de maximizar rentabilidade ante as possibilidades lucrativas impostas pelas condições delineadas nas fases cíclicas de expansão da atividade econômica ou de crescimento sustentado.

${ }^{13}$ No caso das inovações tecnológicas a geração de renda se dará através da compra de bens de capital com novas tecnologias incorporadas e com a aquisição de know-how, de patentes e de novos conhecimentos que possibilitarão a ampliação das capacitações tecnológicas das empresas inovadoras, sendo que tais compras e aquisições têm como contrapartida a remuneração de fatores produtivos empregados na produção daqueles bens de capitais e dos novos conhecimentos adquiridos pelo empresário inovador.
} 
empresários, têm influências, o que implica em criar expectativas quanto à possibilidade e a capacidade efetiva de se efetuar a consolidação financeira das dívidas de curto prazo das empresas. Tais expectativas dependem, de um lado, da demanda por títulos de longo prazo pelos agentes poupadores individuais e investidores institucionais e, de outro, da organização e eficiência dos mercados de capitais em garantir possibilidades, condições e recursos necessários requeridos pelo processo de consolidação financeira das dívidas de curto prazo, garantindo assim que o crédito bancário se constitua em elemento apropriado para o financiamento da acumulação de capital e dos gastos com inovação tecnológica. Ademais, mesmo que tais condições existam e sejam evidentes e reais, a consolidação financeira das dívidas requer que empresas que possuem dívidas de curto prazo, e que apresentem a necessidade de efetuar a consolidação financeira das mesmas, sejam listadas em bolsas de valores. Isso é necessário para que tal processo possa ser concretamente efetivado, de modo a permitir que as mesmas sejam capazes de efetuar a subscrição de novos títulos de longo prazos de dívidas ou de propriedades, condições estas não muito evidentes nos países em desenvolvimento, em processo de catching up, fator este que será analisado a seguir.

\section{FINANCIAMENTO BANCÁRIO E CONSOLIDAÇÃO FINANCEIRA DAS DÍVIDAS DE CURTO PRAZO}

Empresários, diante de incertezas quanto aos retornos dos investimentos ou dos resultados prospectivos da inovação tecnológica que pretendem implementar, têm que estar cientes das condições de obtenção de financiamento via crédito no mercado bancário. Também precisam estar atentos às possibilidades e às condições de efetivar a consolidação financeira das dívidas contraídas pois, como discutido, o finance "está atrelado" ao funding. Podemos dizer que mais do que atrelado, são fenômenos indissociáveis. Ambos são faces da mesma moeda que financia a acumulação de capital e a inovação tecnológica implementadas pelas empresas de países em desenvolvimento.

Desse modo, as decisões de efetuar investimentos e/ou implementar inovações tecnológicas estão na cunha entre as incertezas que condicionam a oferta de crédito (finance) estabelecido pelo comportamento do setor bancário, ante seu comportamento de preferir ou não liquidez, e as incertezas que condicionam o processo de consolidação financeira das dívidas de curto prazo através dos mercados de capitais, ou seja, os fatores condicionantes do funding, conforme Figura 05.

Figura 05 - Fatores determinantes do finance

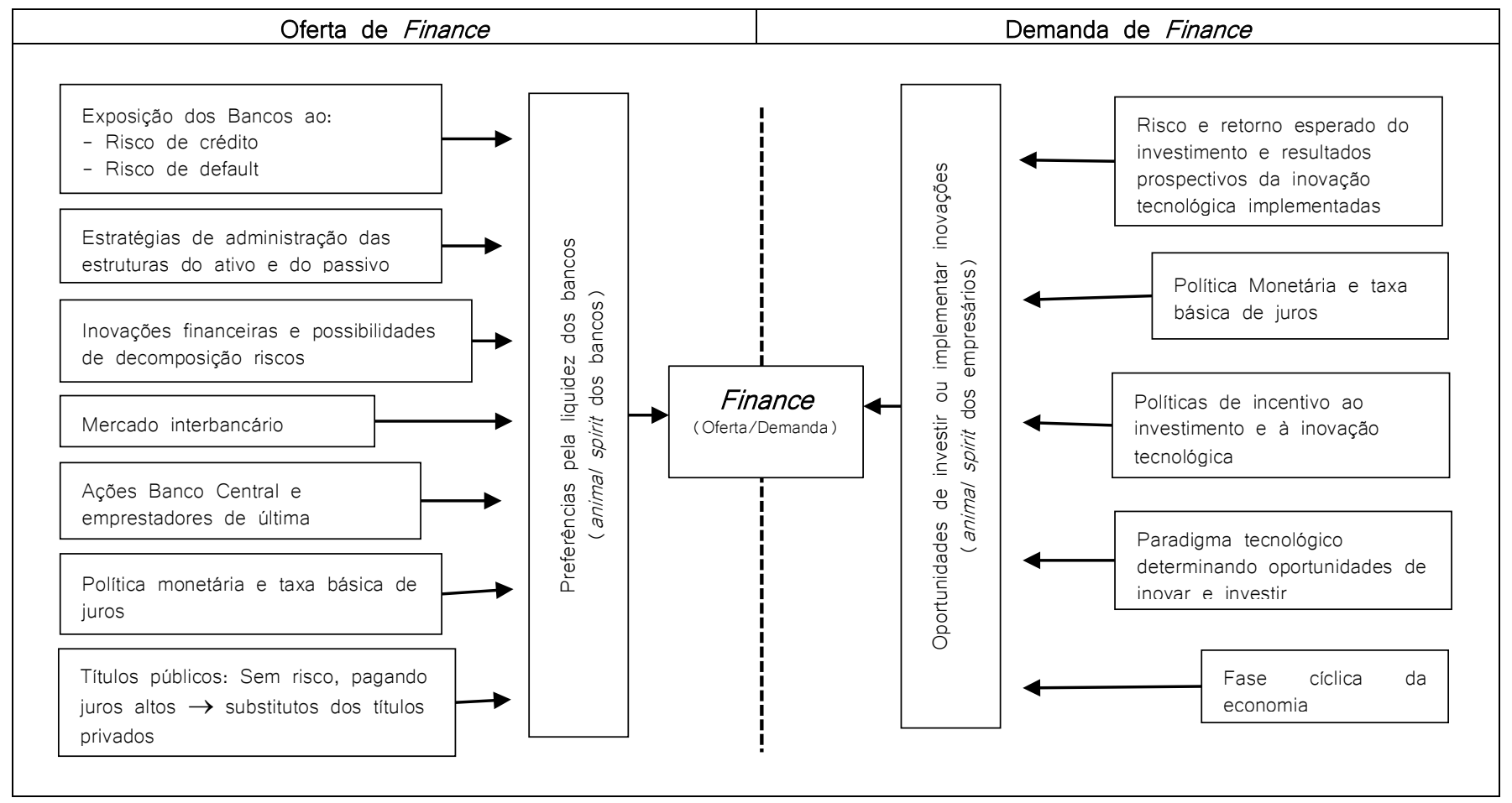

Fonte: Elaboração própria. 
Pode-se afirmar que, no que tange à tomada de decisões quanto a investir e/ou implementar inovações tecnológicas, os empresários devem olhar em perspectiva não apenas em relação aos retornos esperados, mas também em relação às possibilidades e às condicionalidades efetivas de realizar a consolidação financeira de suas dívidas de curto prazo a serem contraídas. O papel e a funcionalidade do setor bancário quanto ao processo de criação de moeda e de fornecimento de crédito para o financiamento do investimento e da inovação tecnológica, bem como o comportamento de preferência por liquidez pelos bancos já se constituem em terreno bastante sedimentado pela abordagem teórica pós-keynesiana, segundo Studart (1985, 1995, 1999), Carvalho (1992, 1997, 2005 2007, 2010), Paula (1998, 1999, 2003), Chick (1993) Kregel (1986, 1998), Davidson (1972, 1986, 1994, 2002, 2011) e Minsky (1982, 2008), entre outros. Entretanto, ainda há a necessidade de se estabelecer um olhar crítico sobre a outra face do mecanismo de financiamento que é o processo de consolidação financeira das dívidas, questão esta que necessita ser melhor entendida e desenvolvida do ponto de vista teórico Avançar nesta área implica primeiro reconhecer que no processo de financiamento do investimento, via crédito bancário, o finance não pode ser pensado de forma independente e dissociado do funding, conforme foi visto acima, mas também que o processo de consolidação financeira das dívidas de curto prazo (funding) é tão importantes quanto as condicionantes do finance.

Outro fator de significativa importância que também deve ser considerado, e que tem relação com o acima discutido, é o surgimento dos fundos mútuos de investimentos e de pensões. ${ }^{14}$ Minsky (1986) já destacou que tais agentes institucionais têm seus objetivos centrados na valorização financeira de seus portfólios, os quais, na maioria das vezes, não são coincidentes com os objetivos das empresas nãofinanceiras sendo, portanto, fonte de instabilidade do capitalismo e influente fator causador da reversão fase cíclica do boom.

Os fundos de investimentos e de pensões tornaram-se os principais demandantes de ativos financeiros de longo prazo na maioria dos países desenvolvidos e em desenvolvimento desde o último quartel do século passado, tornando-se importantes instituições capazes influir nas condições de oferta de recursos financeiros ao financiamento do investimento e da inovação tecnológica. O comportamento desses agentes quanto à valorização de seus portfólios, associado à volatilidade dos preços dos ativos financeiros nos mercados de capitais, conforme acima discutido, constituem fatores importantes para a determinação das condições do processo de consolidação financeiras das dívidas de curto prazo das empresas inversoras e inovadoras. É necessário destacar também que o surgimento e o desenvolvimento de tais instituições financeiras ocorrem em momento histórico do desenvolvimento capitalista de mudança de paradigma tecnológico consubstanciada na passagem do paradigma fordista, centrado na produção e no consumo em massa, para novo paradigma centrado em novas tecnologias de informação e comunicação (TIC). Neste particular, é fundamental que os pensadores da história da tecnologia e da evolução do capitalismo façam esforço não apenas no sentido de incorporar em suas análises os avanços e desenvolvimentos ocorridos no plano das finanças econômicas nacionais, mas sobretudo nas finanças internacionais, com o objetivo de associá-las ao desenvolvimento das novas instituições financeiras e ao surgimento de novos instrumentos financeiros.

Em plano analítico mais abstrato, que tem perdido significativa importância na medida em que a teoria macroeconômica tem se afastado cada vez mais do campo da história e se enveredado pelo campo da modelagem e das análises conjunturais, pode-se afirmar que é cada vez mais difícil pensar de forma dissociada à evolução do capitalismo, ocorrida no plano produtivo, dos avanços pelos quais o mesmo tenha, e tem, passado no plano das finanças. ${ }^{15}$ Apesar de produção e finanças serem coisas distintas, o desenvolvimento capitalista se beneficia da evolução e do progresso que ocorrem simultaneamente em ambas as esferas: da produção e das finanças. Ademais, é praticamente claro e visível, apesar de ainda não se ter uma análise aprofundada sobre o tema, que o surgimento de novas instituições financeiras, tais como fundos mútuos de investimentos e de pensões, seguradoras e corretoras de títulos e valores mobiliários, assim como o surgimento de novos instrumentos financeiros como, por exemplo, debêntures, derivativos,

\footnotetext{
${ }^{14}$ Esse fator tem significativas implicações para o funding e, portanto, para o processo de consolidação financeira das dívidas de curto prazo das empresas que financiam investimento e inovações tecnológicas através do uso da fonte composta pelo crédito bancário de curto prazo.

${ }^{15}$ Quanto a essa questão, ver particularmente Sauviat e Chesnais (2005) e Chesnais e Sauviat (2006).
} 
comercial paper e securities tenham ocorridos em simultâneo, e coincidindo temporalmente, com o momento histórico do aparecimento de novas tecnologias, de novos atores institucionais e novo paradigma tecnológico, conforme tem destacado as abordagens desenvolvidas por Nelson e Winter (2005), Freeman e Pérez $(1986,1988)$ e Dosi (1982, 1988a, 1988b, 2006), Freeman e Soete (2008), entre outros.

Associado a isso, Studart (1999) destaca que a teoria de investimento de Keynes apresenta uma "estrutura [institucional] financeira implícita, baseada em dois pilares básicos: um sistema bancário desenvolvido (para o finance) e a existência de mercados organizados de ações (para o funding)" (STUDART, 1999, p. 162; grifos nossos). O autor destaca ainda que a estrutura institucional financeira da perspectiva pós-keynesiana "[...] não representa um parâmetro que mede a funcionalidade do sistema financeiro, mas sim uma das formas institucionais possíveis para o financiamento da acumulação em economias monetárias" (STUDART, 1999, p. 162). Além disso, deixa também evidente que, da estrutura institucional implícita nas análises de Keynes é possível analisar os problemas relacionados "[...] à separação entre os atos de poupar e de investir, ao hiato temporal entre financiamento e maturação do investimento e à incerteza inerente a tais economias [monetárias de produção]" ${ }^{16}$ (STUDART, 1999, p. 162-3). Este seria basicamente problema de "[...] adiantamento de poder de comando (finance) e compatibilização de estruturas ativas e passivas entre agentes deficitários e superavitários (funding)" (STUDART, 1999, p. 163).

Contudo, Studart (1999), assim como a maioria dos autores pós-keynesianos, não analisa em profundidade o problema referente à compatibilidade entre as estruturas passivas dos agentes deficitários, tomadores de empréstimo, os quais vislumbram retornos prospectivos que deverão advir dos planos de investimentos e de inovações tecnológicas a serem implementadas, e as estruturas ativas dos agentes poupadores individuais e de investidores institucionais (fundos mútuos de investimentos e pensões), os quais tem por objetivo transferir poder de compra, resultante de excedentes de renda, para o futuro. Tal transferência se dá na forma de demanda e posse de ativos financeiros de longo prazo adquiridos nos mercados financeiros e de capitais, ativos esses lançados pelas empresas, em sua maioria, com o propósito de consolidação financeira de suas dívidas de curto prazo. Deve-se destacar também que a solução de problemas de compatibilidade entre as estruturas passivas e ativas dos agentes deficitários e superavitários implica, do ponto de vista teórico e prático, o envolvimento de outros agentes econômicos, além de empresários investidores e inovadores, tomadores de empréstimos bancários, e bancos fornecedores de crédito. Estes outros agentes são as bolsas de valores, as seguradoras, os investidores institucionais, os poupadores individuais e toda gama de políticas econômicas que influenciam a performance da economia em geral, com reflexos sobre as decisões dos agentes quanto a demandar ativos financeiros. É notório destacar, ainda, que estes outros agentes também tomam decisões com base em avaliações subjetivas, a partir de modelos de decisões não-determinísticos, em relação ao comportamento futuro da economia e em relação às suas experiências passadas recentes. Suas ações, entretanto, têm implicações significativas profundas para o processo de consolidação financeira das dívidas de curto prazo, dívidas estas contraídas pelos empresários investidores e inovadores para dar start em seus planos de gastos com investimentos e com inovações tecnológicas.

Ressalta-se, ainda, que a funcionalidade do sistema financeiro, para a questão do financiamento do investimento e da inovação tecnológica resulta da ação simultânea das duas estruturas institucionais: de um lado, um sistema bancário desenvolvido, capaz de responder de forma eficiente e com estabilidade as demandas por crédito e, de outro, um mercado de capitais consolidado e organizado, capaz de proporcionar condições adequadas e profícuas para a consolidação financeira das dívidas de curto prazo, ao garantir não apenas bom funcionamento aos mercados de capitais, mas também demanda por ativos financeiros das empresas inversoras e inovadoras. Sem estes dois pilares institucionais estruturados e consolidados, o financiamento do investimento e da inovação tecnológica a serem implementada pelas empresas, pelo uso de fontes de financiamento de curto prazo como o crédito bancário, apresenta dificuldades de se efetivar, ou se dará de forma truncada e pouco eficiente. Os empréstimos bancários, enquanto fonte de

\footnotetext{
${ }^{16}$ Neste particular, é possível afirmar que Keynes ao propor abordagem sobre o funcionamento de uma economia monetária de produção tinha em mente que ambos os processos econômicos, produtivos e financeiros, não poderiam ser analisados de maneira estanque. Para Keynes (1985), numa economia monetária de produção o desenvolvimento do setor produtivo ocorre em simultâneo ao desenvolvimento do setor financeiro. Finanças e produção de bens e serviços são fenômenos que se complementam dentro do processo de desenvolvimento capitalista.
} 
financiamento, requerem como imperativo complementar a consolidação financeira das dívidas. Isso se dá mesmo que, do ponto de vista avaliativo dos projetos, os retornos esperados dos investimentos ou os resultados prospectivos das inovações sejam superiores aos fluxos de compromissos financeiros. Isso ocorre em razão do descompasso temporal entre os fluxos de caixa das empresas inversoras e inovadoras. Ou seja, mesmo que os projetos de investimentos e as inovações a serem implementadas apresentem resultados financeiros esperados, mesmo que incertos, positivos e superiores aos compromissos financeiros bancários de curto prazo das empresas, o seu tempo de maturação geralmente nunca é menor que o tempo de vencimento de seus passivos financeiro e os retornos financeiros auferidos de maneira alguma serão providos a tempo de forma a proporciona às mesmas condições adequadas de saldarem seus compromissos financeiros resultante das dívidas, proporcionando-lhes condições para o ressarcimento de suas obrigações financeiras no momento adequado requerido pelos compromissos bancários.

Assim, o avanço na compreensão dos fatores determinantes do financiamento do investimento e da inovação tecnológica - esta pensada enquanto decisões de investir, conforme acima discutido - implica pensar simultaneamente não apenas a funcionalidade do sistema bancário em ser capaz de atender as demandas por crédito das empresas inversoras e inovadoras (finance), mas também a funcionalidade dos mercados de capitais estruturados, consolidados e organizados para fazer frente aos requerimentos decorrentes do processo de consolidação financeira das dívidas de curto prazo (funding). De tais requerimentos ter-se-á como imperativo a necessidade de se rever a taxonomia de sistemas financeiros segundo Zysman (1983) tendo em vista que o autor propõe uma tipologia em que faz distinção entre sistema bancário baseado no crédito (credit-based systems) e sistema baseado no mercado de capital (capital market-based systems). A funcionalidade do sistema bancário para o financiamento do investimento e da inovação tecnológica, conforme acima discutida, requer não uma análise centrada na separação dos papeis desempenhados pelos bancos, de um lado, e mercados de capitais, de outro, mas na complementariedade, integração e interação entre ambos os setores: sistema bancário e mercados de capitais, posto que ambos são operacionais e apresentam funções distintas para fases específicas do processo de financiamento, visto este em sua totalidade: do finance ao funding. Desse modo, o que se pretende destacar é que uma teoria do financiamento da acumulação de capital ou da inovação tecnológica, que tenha a pretensão de ser robusta e realista em face aos avanços ocorridos nos sistemas e mercados financeiros na atualidade, requer que a mesma seja estruturada sobre uma compreensão integrada e funcional entre os papeis desempenhados, de um lado, pelos bancos, na concessão de finance e, de outro, pelos mercados de capitais, no processo de consolidação financeira das dívidas de curto prazo (funding).

Do ponto de vista o processo de consolidação financeira das dívidas de curto prazo, qual a funcionalidade do sistema bancário baseado no mercado de capital (capital market-based systems) para o financiamento do investimento e da inovação tecnológica, sendo este sistema pensado e desempenhando papel distinto e independente do sistema bancário? Em que sentido os sistemas financeiros baseados nos mercados de capitais podem contribuir e auxiliar no financiamento do investimento e da inovação tecnológica de maneira unitária se o processo de consolidação das dívidas de curto prazo requer ações conjuntas e coordenadas entre bancos e mercados de capitais? De outras parte, em países nos quais predomina sistema financeiro baseado no mercado de crédito, ${ }^{17}$ e seus mercados de capitais são ainda incipientes, desestruturados e pouco eficientes quanto ao processo de consolidação financeira das dívidas de curto prazo, qual o papel dos bancos e qual a funcionalidade e a eficácia do crédito bancário para o financiamento do investimento e da inovação tecnológica, tendo em vista que nestas condições o processo de consolidação das dívidas de curto prazo torna-se ainda mais difícil? Fica óbvio, portanto, a necessidade de se evidenciar elementos teóricos que possam contribuir para o entendimento de que a funcionalidade do crédito bancário para o financiamento da acumulação de capital e da inovação tecnológica não apenas só faz sentido se o sistema financeiro e os mercados de capitais forem pensados enquanto instituições com papeis diferenciados, mas complementares no processo de financiamento. Nesse sentido, é necessário destacar elementos que possam contribuir para a ideia de que os países em desenvolvimento, em processo de catching up, devem estabelecer especial atenção na estruturação de seus agentes financeiros, sejam eles

\footnotetext{
${ }^{17}$ Conforme Studart (1999), corroborando Zysman (1983): “[os] países em desenvolvimento (os quais, como mostra Zysman, em geral possuem sistemas financeiros com base em crédito" (STUDART, 1999, p. 164), e ao afirmar que "a maior parte dos países em desenvolvimento parece dotada de um sistema financeiro com base no crédito" (STUDART, 1999, p. 164).
} 
bancários ou pertencentes ao mercado de capitais, como forma de garantir bases mais efetivas para a concretização dos mecanismos de financiamento do investimento e da inovação. Um sistema financeiro mais integrado e consolidado nos países em desenvolvimento contribuiria por reduzir a distância que os separam em relação aos países tecnologicamente avançados. Nesse sentido, fica evidente a necessidade de uma revisão crítica sobre a taxonomia de sistema financeiro apresentada por Zysman (1983) com vista a buscar incorporar nela elementos que possam contribuir para a compreensão do papel do sistema financeiro e dos mercados de capitais para o financiamento da acumulação de capital e da inovação tecnológica nos países em desenvolvimento.

A consolidação financeira de dívidas envolve lançamento de novos títulos, ou se processa através de renegociações de títulos já emitidos? Em que sentido o processo de consolidação financeira das dívidas de curto prazo se diferencia do processo de alavancagem de recursos financeiros realizado pelas empresas através dos mercados de capitais? Para responder tais questões é necessário avançar um passo na compreensão do fenômeno do processo de financiamento do investimento e da inovação. É preciso também evidenciar os agentes e as relações que estão por trás do processo de financiamento do investimento e da inovação tecnológica de tal modo a evidenciar os papeis e as funções relativas que os mesmos exercem no processo de financiamento com vistas a torna-los eficazes e funcionais para o desenvolvimento econômico tanto para os países desenvolvidos quanto para os em desenvolvimento, ou em processo de catching up.

Portanto, a consolidação financeira das dívidas de curto prazo resulta no aprofundamento da abertura do capital da empresa que necessita vender novos títulos de dívidas ou ações de longo prazo no mercado de capitais para substituir os títulos de dívidas de curto prazo existente seu passivo financeiro, na forma de dívidas bancárias, de maneira a compatibilizar os fluxos de caixas compostos pelos retornos esperados do investimento, ou dos resultados prospectivos das inovações tecnológicas, com os seus compromissos financeiros. Isso significa, portanto, que para realizar a consolidação financeira de dívidas de curto prazo a empresa tenha seu capital aberto e seja listada em bolsa de valores, pois se assim não for, fica descartada a possibilidade de lançamento de títulos de dívidas ou ações, conforme Figura 06. Desse modo, a consolidação financeira das dívidas de curto prazo requer não apenas a abertura de capital - ou seja, a listagem da empresa em bolsa de valores - e o lançamento de novos títulos de dívidas ou de propriedades - o que, por sua vez, implica em ampliar sua participação nos mercados de capitais - mas também o aprofundamento de seu valor negociado nos mercados de capitais.

Figura 06 - Dinâmica das ações dos poupadores individuais e dos fundos mútuos de investimentos e de pensões

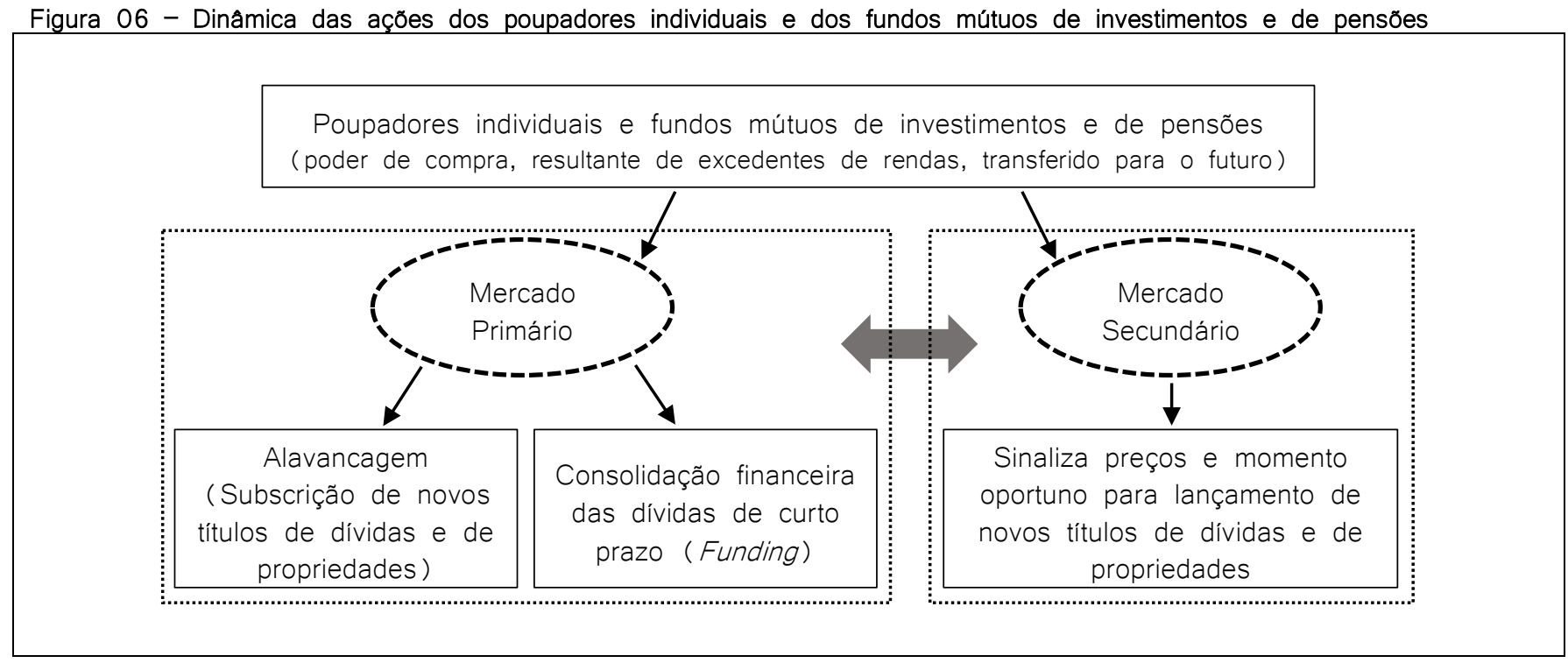

Fonte: Elaboração própria.

Contudo, grande parte das empresas que implementam inovações tecnológicas através da aquisição de bens de capital com novas tecnologias incorporadas, ou que adquire know-how, patentes ou novos conhecimentos como forma de ampliar suas capacitações tecnológicas não tem o capital aberto, ficando, portanto, impossibilitada de efetuar a consolidação financeira de suas dívidas de curto prazo nos mercados de capitais. Este fator agrava as condições de financiamento do investimento e da inovação tecnológica, 
sobretudo das empresas não líderes em tecnologias nos setores em que atuam, ou dos países em desenvolvimento, em processo de catching $u p .^{18}$

Outro fator importante a ser considerado é que a subscrição de novos títulos e ações, com vistas à alavancagem direta de recursos para serem aplicados em projetos de investimentos ou inovações tecnológicas, não apresenta o imperativo condicional determinado por uma data específica para seu lançamento. A subscrição de novos títulos e ações com vistas a alavancar recursos que não sejam destinados meramente à consolidação financeira de dívidas tem mais liberdade quanto a data em que a mesma pode ser realizada. As dívidas que deverão ser consolidadas nos mercados de capitais têm prazos de vencimentos estabelecidos através dos contratos de empréstimos bancários, cujos prazos são bem definidos. Desse modo, seus prazos de vencimentos define a necessidade imperativa de uma data específica para as empresas efetuarem a consolidação financeira das mesmas, determinando assim o momento exato para as empresas endividadas lançarem nos mercados de capitais novos títulos com vista a levantar recursos a serem usados na consolidação financeira. Este é o caso, por exemplo, do lançamento de novos títulos e ações visando o alargamento dos prazos das dívidas de curto prazo a vencer, dívida estas contraídas junto aos bancos, posto que tais prazos são contratuais. Neste caso específico, a empresa endividada não conseguem esperar ou, quando muito, aguardar o momento oportuno para subscrever novos títulos tendo em vista o imperativo contratual estabelecido pela data de vencimento de suas dívidas contraídas junto aos bancos. ${ }^{19}$ Assim, o processo de subscrição de novos títulos e ações que não sejam destinados à consolidação financeira de dívidas, mas tão somente para alavancar recursos financeiros via mercados de capitais para serem aplicados em projetos de investimentos e inovações, caracteriza-se por ter mais liberdade e facilidades de ser implementado, podendo aguardar o momento propício e adequado, indicado pelo comportamento dos preços dos títulos e ações da empresa negociados nos mercados secundários, não obstante a possível ocorrência de emergência quanto a necessidade de implementar investimentos e gastos inovativos. Portanto, o papel desempenhado pelo mercado de capitais no que diz respeito ao provimento de recursos às empresas para financiar investimento e inovação tecnológica tem dois componentes básicos: o primeiro está relacionado com a subscrição pelas empresas de novos títulos e ações, objetivando com isso alavancar recursos financeiros para serem aplicados diretamente em seus projetos de investimento e inovações; o segundo, está relacionado com a alavancagem de recursos visando especificamente a consolidação financeira de suas dívidas.

$\mathrm{Na}$ hipótese de a empresa ser capaz de obter os recursos requeridos, tem-se como resultado duas consequências: a primeira, está relacionada ao fato de os recursos alavancados serem destinados especificamente para o financiamento e novos planos de investimentos e de inovações. Neste caso, tem-se que não apenas a ampliação das possibilidades de financiamento, mas também a possibilidade de pulverização da propriedade que, por sua vez, traz consigo o risco da perda de controle sobre seu capital, razão pela qual esta é a forma menos preferida pelas empresas para se obter recursos financeiros, conforme estabelece a pecking order theory; ${ }^{20}$ a segunda, está relacionada com o fato dos recursos alavancados nos mercados primários serem destinados especificamente para o processo de consolidação financeira de dívidas. Neste caso, deve ocorrer simultaneamente mudanças no seu grau de endividamento, posto que ao conseguir efetuar a consolidação de suas dívidas tem-se como consequência a alteração no perfil de seus

\footnotetext{
${ }^{18}$ Nesse sentido, a inovação tecnológica implementada pelas empresas dos países em desenvolvimento, sendo predominantemente originadas de mecanismos de difusão tecnológica, tem como consequência atenuar os efeitos do financiamento na medida em que tais inovações já apresentam suas viabilidades técnicas e financeiras (retornos) consolidadas, possibilitando portanto o confronto de sua eficiência marginal do capital, na concepção de Keynes, com o custo dos recursos financeiros alavancados para seu financiamento, balizando assim o seu financiamento através do uso de recursos de terceiros.

${ }^{19}$ Se até a data de vencimento de suas dívidas a empresa não possuir os recursos próprios requeridos para saldá-las, ou não conseguir efetuar a consolidação financeira das mesmas, então não restará alternativa a não ser dar início ao processo de rolagem delas junto aos bancos. A rolagem, entretanto, se dará nas condições e nos termos determinados não apenas pelas circunstâncias conjunturais estabelecidas pelo mercado de crédito bancário e pela preferência pela liquidez dos bancos no momento em que acontece, mas também por influências de fatores relacionados à conjuntura econômica e à fase cíclica pela qual passa a economia, conforme analisado.

${ }^{20}$ Segundo a pecking order theory, as empresas apresentam uma estrutura de capital que está correlacionada não apenas com as oportunidades de investimentos, mas também com o uso de fontes apropriadas de financiamento dos mesmos. Desse modo, financiam seus gastos estabelecendo uma ordem de preferência hierárquica quanto às fontes de financiamento utilizadas, com preferências às fontes internas em relação às fontes de terceiros, como título de dívidas ou emissão de ações. Esta hierarquia decorre dos custos e riscos relativos envolvidos a cada uma das alternativas. Nesse sentido, David et al. (2009) ao analisar a aplicabilidade dessa teoria realizaram investigações sobre o comportamento das empresas brasileiras quanto a endividar-se ou distribuir dividendos durante o período de elevado valorização das bolsas de valores que ocorreu em simultâneo ao período de crescimento sustentado: de 2000 a 2006 . Segundo os autores, "os resultados indicam que a teoria do pecking order é mais consistente para explicar a determinação da estrutura de capital das empresas brasileiras. A lucratividade foi a variável mais significativa e negativamente relacionada ao endividamento, o que prescreve que as empresas mais lucrativas são menos endividadas. Isso dá credibilidade ao modelo pecking order, que defende a hierarquização das fontes de financiamento". (DAVID et al., 2009, p. 152).
} 
passivos, com a redução da participação de seus passivos de curto prazo e o aumento da participação de seus passivos de longo prazo.

Na hipótese de a empresa, por qualquer razão, não conseguir alavancar, via os mercados de capitais, os recursos requeridos para financiar seus planos de investimentos e inovações tecnológicas, ou para a consolidação financeira de suas dívidas, tem-se também duas outras consequências. A primeira, resulta no fato de a empresa não conseguir implementar seus planos de investimento e inovações por razões de restrições em sua capacidade de financiá-los. Nesse caso a empresa tem a necessidade de rever ou redimensionar seus planos de expansão ou de inovações, com repercussões sobre seu dinamismo produtivo e tecnológico. A segunda está relacionada como o processo de consolidação de suas dívidas. Nesse caso a empresa se vê obrigada a estabelecer processo de renegociação de suas dívidas com os bancos sob formas e termos estabelecidos pelo mercado de crédito bancário no momento de renegociação de suas dívidas. Isso pode ter implicações não apenas em termos do seu grau de endividamento, com reflexos sobre os custos do estoque de seus passivos financeiros, mas também em termos da possibilidade de potencializar os riscos de concordata e falência, caso as mesmas se arriscam a ampliar seus recursos produtivo, ou a implementar novas tecnologias financiando-as através do crédito bancário.

A alavancagem de recursos financeiros pelas empresas através da subscrição de título e ações nos mercados primários destinados especificamente para o financiamento de investimentos e de inovações tecnológica não implica a necessidade da presença dos bancos na constituição do fundo de recursos. Os bancos são afetados apenas enquanto agentes subscritores dos novos títulos e ações a serem lançados, beneficiando-se apenas da corretagem. Esta forma de obtenção de recursos financeiros pelas empresas faz com que os bancos atuem apenas como instituições que compõem o sistema de pagamentos na economia. Ou seja, é uma forma de obtenção de recursos financeiros em que há uma relação direta entre a empresa emissora e os novos proprietários de títulos e ações. Entretanto, a alavancagem de recursos financeiros pelas empresas através dos mercados de capitais destinados especificamente para o processo de consolidação financeira das dívidas tem efeitos e impactos diferenciados em relação aos bancos. Estes além de subscritores têm as dívidas das empresas clientes quitadas, com repercussões sobre seu grau de endividamento. Essa constitui-se em uma forma, digamos, indireta de obtenção de recursos via mercados de capitais uma vez que os recursos financeiros são contratados inicialmente com os bancos, através de empréstimos e dívidas, e posteriormente tais dívidas são convertidas em títulos e ações subscritos em mercados primários como forma de quitá-las junto aos agentes financiadores (os bancos) através do processo de consolidação financeira das mesmas.

\section{CONSIDERAÇÕES FINAIS}

O financiamento da inovação tecnológica não deve ser analisado de forma independente do processo de consolidação financeira das dívidas de curto prazo das empresas inversoras e inovadoras. Na verdade, o processo de financiamento da inovação tecnológica, ou mesmo da acumulação de capital, inicia-se com a contração de dívidas pelas empresas, com a alavancagem de recursos de terceiros de curto prazo via, por exemplo, o crédito bancário, e finaliza com a consolidação financeira de tais dívidas. É a partir dessa perspectiva mais geral e abrangente que se deve estabelecer as bases para uma teoria do financiamento da inovação e do investimento, independentemente das diferentes especificidades relacionadas a cada tipo de gastos. Desse modo, buscou-se demonstrar a existência de uma articulação, favorável ao financiamento, entre o setor bancário, fornecedor de finance, e o sistema de mercados de capitais, estruturador do funding, de fundamental importância para o financiamento da inovação tecnológica e do investimento. Tal articulação deve ter seu papel de centralidade em uma teoria mais abrangente sobre o financiamento do investimento e da inovação tecnológica, o que se torna ainda mais importante para países em desenvolvimento, dadas as características da dinâmica e do processo inovativo prevalecente nesses países, estruturadas sobremaneira na difusão tecnológica e no acesso a novos conhecimentos já consolidados.

Conforme analisado, os recursos de curto prazo, como por exemplo o crédito bancário, só se tornam em alternativa plausível enquanto fonte de financiamento do investimento e da inovação tecnológica se houver articulação e complementariedade nos papeis desempenhados por ambas as instituições: bancos, fornecendo finance, e mercados de capitais, proporcionando possibilidades e condições efetivas para o 
funding. Nesse sentido, buscou-se estabelecer que os empresários inversores ou inovadores, no momento da tomada de suas decisões, devem ter clareza e estar seguros não apenas em relação aos retornos prospectivos esperados dos investimentos e das inovações tecnológicas a serem implementadas, mas também em relação às possibilidades e condições efetivas de consolidação de suas dívidas de curto prazo. Tal consolidação é imprescindível e fundamental tendo em vista que frequentemente não há coincidência entre os prazos de retornos prospectivos dos investimentos e das inovações implementadas e os prazos relativos aos compromissos financeiros, impostos pelas dívidas de curto prazo, contraídas junto aos bancos. É nessa cunha que os mercados de capitais ganham relevância. Além disso, também argumentou-se no sentido de mostrar que as decisões de implementar inovações devem ser consideradas decisões de investir, tomadas pelos empresários. Esses, ao tomarem tais decisões, devem considerar não apenas se os retornos esperados devem ser superiores aos compromissos financeiros respectivos às dívidas contraídas para o financiamento, mas também devem ter em mente as condições de consolidação destas dívidas, posto que as mesmas têm por imperativo a necessidade de serem consolidadas, ou "fundadas", conforme terminologia de Keynes. Dessa maneira, o finance só pode constituir-se em uma alternativa de financiamento se diretamente associado ao funding. Como se procurou deixar claro, as possibilidades e condições sobre as quais os empresários podem efetuar a consolidação financeira de suas dívidas de curto prazo constitui-se em importante fator determinante das decisões e do volume de gastos a serem implementados em investimentos e inovações.

Procurou-se demonstrar também que o processo de consolidação financeiras das dívidas de curto prazo está relacionado com o comportamento dos agentes poupadores individuais e institucionais - fundos mútuos de investimentos e de pensões - em transferir, para o futuro, e manter poder de compra resultante de excedentes de rendas. A transferência de poder de compra para o futuro se dá predominantemente através da aquisição e manutenção em portfólio de títulos de longo prazo e ações resultantes de aplicações financeiras por tais agentes. A demanda por tais títulos e ações, efetuada pelos agentes poupadores, é fator fundamental condicionante das possibilidades de consolidação financeira das dívidas de curto prazo das empresas na medida em que impõe, ou não, limites ao lançamento de novos títulos de longo prazo, de dívidas e/ou de propriedades, para as empresas necessitadas de efetuar o alongamento dos prazos de suas dívidas, sendo que essa demanda por novos títulos e ações também sofre influências que decorrem da performance da economia segundo as fases cíclicas pela qual a mesma passa. Em períodos de expansão das atividades produtivas e/ou de crescimento sustentado há o aumento da demanda por esses novos títulos e ações, demanda essa influenciada não apenas da expansão da renda agregada na economia, mas também pelo próprio desempenho financeiro das empresas. O contrário ocorre nas fases de retração das atividades produtivas e/ou de recessão/depressão econômica. Nessas, a demanda por novos títulos e ações cai. Isso tem repercussões sobre as possibilidades e condições efetivas de consolidação financeira das dívidas de curto prazo das empresas inversoras e inovadoras, fator esse que, em última análise, afeta suas decisões de investir ou de implementar gastos com inovações tecnológicas, quando tais decisões devem ser financiadas com recursos decorrentes do crédito bancário.

Se há articulação e complementariedade nos papeis desempenhados pelo sistema bancário e pelos mercados de capitais no que tange ao financiamento do investimento e das inovações tecnológicas, então a taxonomia proposta por Zysman, composta por sistemas baseados no credito (credit-based systems) e nos mercados de capitais (capital market-based systems) enquanto modos alternativos de financiamento, requer qualificações. Os argumentos desenvolvidos no longo do artigo permitem uma crítica à taxonomia na medida em que, para Zysman, os sistemas financeiros são vistos como estruturas alternativas de suporte para o financiamento. Entretanto, da perspectiva dos argumentos apresentados neste trabalho, o financiamento da inovação tecnológica, baseado no uso de fontes de recursos de terceiros, tende a ser mais adequado se for pensado enquanto componente que requer integração entre bancos, com a concessão de crédito, e mercados de capitais, com o processo de consolidação financeira das dívidas, incorridas pelas empresas para "startar" gastos com investimentos e inovações. Nesse sentido, demonstrou-se que, mais do que estruturas alternativas de financiamento, banco e mercados de capitais são instituições cujos papeis devem ser vistos como complementares e, ao assim agirem, podem viabilizar, de forma mais eficaz e efetiva, o financiamento para a inovação tecnológica, sobretudo para os países em desenvolvimento, em processo de catching up. 
Demonstrou-se também que o processo de consolidação financeiras das dívidas das empresas requer que tanto o mercado de crédito bancário quanto os mercados de capitais atuem de forma complementar, visando propiciar às empresas inversoras e inovadoras não apenas o finance em volume e condições adequadas aos seus planos de investir e de inovar, assim como garantir as possibilidades e condições efetivas para o funding, sustentando, portanto, a consolidação financeira das dívidas. Desse modo, ambos os setores contribuem, cada qual em seus respectivos campos de atuação, para que o mecanismo financefunding, da perspectiva pós-keynesiana, torne-se de fato alternativa para o financiamento, segundo o que estabeleceu Keynes. Portanto, uma teoria do financiamento do investimento e da inovação tecnológica deve avançar estruturada sobre preceitos básicos de que, mais do que formas alternativas, existem complementariedades entre as ações estabelecidas pelos bancos e pelo mercado de capitais, que sustentam o processo de consolidação financeira das dívidas de curto prazo. Mais que isso, os países em desenvolvimento, ou em processo de catching up, devem estruturar seus sistemas bancários e seus mercados de capitais de forma a torná-los funcionais para as demandas impostas pelos processos de desenvolvimento econômico (investimento) e pelo progresso tecnológico (inovação).

Desse modo, o processo de financiamento do investimento e da inovação não pode ser pensado dentro de um escopo teórico que compartimentalize o papel e as funções dos bancos e dos mercados de capitais, mas a partir de uma concepção teórica pautada na ação integrada desses dois componentes do sistema financeiro.

\section{REFERÊNCIAS BIBLIOGRÁFICAS}

BOIANOVSKY, M. Uma Nota Introdutória aos Artigos de Kalecki, Keynes e Ohlin Literatura Econômica, v. 9, n. 2, p. 121-136. Reimpresso: IPEA. Clássicos de Literatura Econômica. Rio de Janeiro: IPEA, p. 291-305, 1992.

CARVALHO, F. C. de. Mr. Keynes and the Post Keynesians: Principles of Macroeconomics for a Monetary Production Economy. Cheltenham: Edward Elgar, 1992.

. Financial Innovation and the Post Keynesian Approach to the 'Process of Capital Formation'.

Journal of Post Keynesian Economics, v. 19, n. 3, p. 461-487, 1997.

. Sistema Financeiro Brasileiro: a modernização necessária. In: SICSÚ, J.; PAULA, L. F. de;

MICHEL, R. (Orgs.). Novo-Desenvolvimentismo: um projeto nacional de crescimento com equidade social. Rio de Janeiro: Fundação Konrad Adenauer, 2005.

. Sobre a Preferência pela Liquidez dos Bancos. In: PAULA, L. F. de; OREIRO, J. L. (Orgs.).

Sistema Financeiro: Uma Análise do Setor Bancário Brasileiro. Rio de Janeiro: Elsevier, 2007.

Reformas Financeiras para Apoiar o Desenvolvimento. In: IPEA - Instituto de Pesquisa

Econômica Aplicada. Macroeconomia para o Desenvolvimento: Crescimento, estabilidade e emprego.

Brasília: IPEA, p. 309-330, 2010, (Capítulo 10).

CHESNAIS, F.; SAUVIAT, C. O Financiamento da Inovação Tecnológica no Contexto Atual da Acumulação Financeira. In: PELAEZ, Victor; SZMRECSÁNYI, T. (Orgs.) Economia da Inovação Tecnológica. São Paulo: Hucitec/Ordem dos Economistas do Brasil, 2006.

CHICK, V. Macroeconomia Após Keynes: Um reexame da Teoria Geral. Rio de Janeiro: Forense Universitária, 1993.

. A Evolução do Sistema Bancário e a Teoria da Poupança, do Investimento e dos Juros". In:

CHICK, V. Sobre Moeda, Método e Keynes: Ensaios escolhidos. Campinas-SP: Editora da UNICAMP, 2010, (Capítulo 12).

DAVID, M.; NAKAMURA, W. T.; BASTOS, D. D. Estudo dos modelos trade-off e pecking order para as variáveis endividamento e payout em empresas brasileiras (2000-2006). RAM - Revista de Administração Mackenzie, v. 10, n. 6 (Edição especial), nov-dez 2009.

DAVIDSON, P. (1972). Money and the Real World. London: MacMillan, 1972.

. Finance, Funding, Saving, and Investment. Journal of Post Keynesian Economics, v. 9, n. 1, p.

101-110, autumn, 1986.

. Post Keynesian Macroeconomics Theory. Aldreshot: Edward Elgar, 1994.

. Financial Markets, Money and the Real World. Cheltenham: Edward Elgar, 2002 
. John Maynard Keynes. São Paulo: Actual, 2011.

DOSI, G. Technological Paradigms and Technological Trajectories: A suggested interpretation of the determinants and directions of technical change. Revista Brasileira de Inovação, v. 5, n. 1, p. 17-32, janjul, 1982, (Seção: Ideias Fundadoras).

. The Nature of the Innovative Process. In: DOSI, G.; FREEMAN, C.; NELSON, R. R.; SILVERBERG, G.; SOETE, L. (Eds.) (1988). Technical Change and Economic Theory. London/New York, Pinter Publishers, p. 221-238, 1988a, (Chapter 10).

. Sources, Procedures and Microeconomic Effects of Innovation. Journal of Economic Literature, v. 26, n. 3, p. 1120-1171, Sept, 1988b.

. Mudança Técnica e Transformação Industrial: A teoria e uma aplicação à indústria dos semicondutores. Campinas-SP: Editora da UNICAMP, 2006.

FREEMAN, C.; PÉREZ, C. The Diffusion of Technical Innovations and Changes of Techno-Economic Paradigms. Paper presented at the Innovation Diffusion Conference, Venice, 17 and 21 March 1986, (mimeo).

. Structural Crises of Adjustment: Business cycles and investment behaviour. In: DOSI, G. et al. (Eds.). Technical Change and Economic Theory. London/New York: Pinter Publishers, p. 38-66, 1988, (Chapter 3).

FREEMAN, C.; SOETE, L. A Economia da Inovação Industrial. Campinas-SP: Editora da UNICAMP, 2008.

GRASSI, R. A. Capacitações Dinâmicas, Coordenação e Cooperação Interfirmas: As visões FreemanLundvall e Teece-Pisano. Estudos. Econômicos. São Paulo, v. 36, n. 3, p. 611-635, julho-setembro 2006.

IPEA - Instituto de Pesquisa Econômica Aplicada. Clássicos de Literatura Econômica. Rio de Janeiro: IPEA, 1992.

KALECKI, M. Teoria da Dinâmica Econômica - Ensaios sobre as mudanças cíclicas e a longo prazo das economias capitalistas. São Paulo, Nova Cultural, 1985 (Os Economistas).

KEYNES, J. M. The distinction between a co-operative economy and an entrepreneur economy. In: MOGGRIDGE, D. E. (Org.). The Collected Writings of John Maynard Keynes. London: MacMillan, p. 76-87, 1933a, (Volume XXIX).

. A monetary theory of production. In: MOGGRIDGE, D. E. (Org.). The Collected Writings of John Maynard Keynes. London: MacMillan, p. 408-411, 1933b, (Volume XIII).

KEYNES, J. M. Teorias Alternativas da Taxa de Juros. Literatura Econômica, v. 9, n. 2, p. 147-158, 1987 a. Reimpresso: IPEA (1992). Clássicos de Literatura Econômica. Rio de Janeiro, IPEA, p. 317-327. Publicação original: KEYNES, J. M. Alternative theories of the rate of interest. The Economic Journal, v. 47, n. 186, p. 241-252, June 1937a.

. A Teoria ex ante da Taxa de Juros. Literatura Econômica, v. 9, n. 2, p. 165-172, 1987 b. Reimpresso: IPEA (1992). Clássicos de Literatura Econômica. Rio de Janeiro, IPEA, p. 335-341. Publicação original: KEYNES, J. M. "The 'ex-ante' theory of the rate of interest". The Economic Journal, v. 47, n. 188 , p. 663-669, Dec 1937 b.

Economistas).

A Teoria Geral do Emprego, do Juro e da Moeda. São Paulo: Nova Cultural, 1985, (Os

KREGEL, J. A. A Note on Finance, Liquidity, Saving, and Investment. Journal of Post Keynesian Economics, v. 9, n. 1, p. 91-100, autumn 1986.

. The past and future of banks. Quaderni di Ricerche, v. 21. Roma: Bancaria Editrice, 1998.

LIMA, G. T.; SICSÚ, J.; PAULA, L. F. de (Orgs.). Macroeconomia Moderna: Keynes e a economia contemporânea. Rio de Janeiro: Campus, 1999.

LUNDVALL, B. A. Innovation as an interactive process: from user-producer interaction to the national system of innovation. In: Dosi, Giovanni et al., Technical change and economic theory. London/New York: Pinter Publishers, 1988.

MINSKY, H. P. Can “It” Happen Again? Essays on Instability and Finance. New York: M. E. Sharpe, 1982.

The Evolution of Financial Institutions and the Performance of the Economy. Journal of

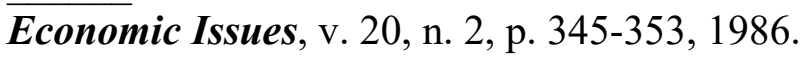


. Stabilizing an Unstable Economy. New York, MacGraw Hill, 2008.

NELSON, R. R.; WINTER, S. G. Uma Teoria Evolucionária da Mudança Econômica. Campinas-SP: Editora da UNICAMP, 2005.

PAULA, L. F. de. Comportamento dos Bancos, Posturas Financeiras e Oferta de Crédito: De Keynes a Minsky. Revista Análise Econômica, v. 16, n. 29, p. 21-38, 1998.

Dinâmica da Firma Bancária: Uma abordagem não-convencional. Revista Brasileira de Economia, v. 53, n. 3, p. 136-142, 1999.

. Financiamento, Crescimento Econômico e Funcionalidade do Sistema Financeiro: Uma abordagem pós-keynesiana. Estudos Econômicos, v. 43, n. 2, p. 363-396, 2003.

SAUVIAT, C.; CHESNAIS, F. As transformações das relações salariais no regime de acumulação financeira. In: LASTRES, H. M. M.; CASSIOLATO, J. E.; ARROIO, A. (Orgs.) (2005). Conhecimento, Sistemas de Inovação e Desenvolvimento. Rio de Janeiro: Editora UFRJ/Contraponto, 2005.

SCHUMPETER, J. A. A Teoria do Desenvolvimento Econômico - Uma Investigação Sobre Lucros, Capital, Crédito, Juro e o Ciclo Econômico. São Paulo: Abril Cultural, 1982, (Os Economistas).

. Capitalismo, Socialismo e Democracia. Rio de Janeiro: Zahar Editores, 1984.

STUDART, R. Investiment Finance in Economic Development. London: Routledge, 1985. . The Efficiency of Financial Systems, Liberalization, and Economic Development. Journal of Post

Keynesian Economics, v. 18, n. 2, p. 269-292, 1995.

. O Sistema Financeiro e o Financiamento do Crescimento: Uma alternativa pós-keynesiana à visão

convencional. In: LIMA, G. T.; PAULA, L. F. de (Orgs.). Macroeconomia Moderna: Keynes $\boldsymbol{e}$ a Economia contemporânea. Rio de Janeiro: Campus, 1999, (Capítulo 6).

ZYSMAN, J. Governments, Markets, and Growth: Financial Systems and the Politics of Industrial

Growth. Oxford: Martin Robertson, 1983. 